\title{
Nātyaśāstra and Abhinavabhāratī: Trends and Open Questions
}

In this chapter, I briefly introduce the sources for this study, emphasizing three temporal and contextual layers I have attempted to keep distinct: that of the Nātyaśāstra, that of the Abhinavabhäratī, and that of the modern reception of the Nātyaśāstra-Abhinavabhāratī complex. This third layer will be dealt with first, since it is the context that is temporally closer to us: all the different editions at our disposal, which have contributed to shaping ideas and prejudices about these two texts, were produced within a time span of about a hundred years, a period that is worth addressing. The history of the printed editions will be furthermore set against the specific background of research on Indian dance, with a focus on interpretations of the verbal descriptions of dance movements in the text of the Nâtyaśāstra vis-à-vis their visual depictions in temple sculpture.

The date of the Nātyaśāstra and the identity of its author are still shrouded in mystery, and so too are the practices recorded in it. Taking into account the structure of the text as it has been handed down to us, with its various layers alternating narrative and pedagogical content, allows us to address the question of whether its composition was unitary, as well as the multiple issues pointed out by previous scholars in this connection, including the problematic position of the fourth chapter and its presentation of dance movements. A closer look at the place of dance within Bharata's text and its narrative, in turn, helps in better situating Abhinavagupta's discussion of the nature of dance and dramatic acting, which is the main topic of this book, as firmly grounded in Bharata's text.

Finally, the paucity of historical evidence on the Nātyaśāstra-and, consequently, its intrinsically problematic value for a study of the performing arts in ancient India - is contrasted with the wealth of details about Sanskrit drama and dance in Kashmir at the turn of the first and the second millennia, as drawn from the Abhinavabhäratī. Not only does Abhinavagupta's commentary record artistic practices and theories current at his time but, through the incorporation of older debates and intertextual reference to other works, it allows us to cast a glance on their history as well. 


\subsection{Editorial History and Textual Reception}

The first-ever edition of the text of the Nātyaśästra, although incomplete, was published in 1865 by Fitz-Edward Hall as an appendix to his edition of Dhanañjaya's Daśarūpaka. After the fortuitous discovery of a complete manuscript of the Nātyaśāstra, just one day after completing his preface to the Daśarūpaka, Hall decided in fact to edit, along with it, four chapters of Bharata's text. ${ }^{1}$ These chapters dealt essentially with the literary aspects of playwriting, namely the dramatic genres (daśarūpakalakșaṇa) (ch. 18), plot divisions (añgavikalpa) (ch. 19), manner divisions (vrttivikalpa) (ch. 20) and dramatic characters (prakrtyadhyāya) (ch. 34). ${ }^{2}$ This marked the beginning of philological studies on the Nātyaśāstra, which had been preceded, by almost a century, by the European 'discovery' of Sanskrit drama through the acclaimed translation of the Abhijñannaśäkuntala by William Jones in $1789,{ }^{3}$ followed by the translation of five Sanskrit plays by H.H. Wilson in 1827.4

The second part of the nineteenth century saw the publication of many Sanskrit plays in translation, as well as the first attempts to edit the text of the Nätyaśāstra, which led to the partial editions of the French scholars Paul Regnaud ${ }^{5}$ and Joanny Grosset, ${ }^{6}$ along with the important study on Indian theatre

1 In the footnotes to his edition, Hall quotes fragments of the Nś from an incomplete manuscript containing chapters 1 to 7 , as well as passages from the commentaries on the Sanskrit plays. In his preface, he expresses the idea that the Daśarūpaka had long been a 'favourite authority, among Hindus, for everything connected with the theatre' (Hall 1865: 1), and rectifies it in a postscript dated 1862, after the discovery of a complete copy of the 'Institute of Mimetics', i.e. the Nātyaśāstra (ibid.: 37).

2 The numbering of the chapters corresponds to Hall's manuscript, and the task of editing them was assigned to E.B. Cowell (Hall 1865: 37). According to Heymann (1874: 89) and Grosset (1898: iii), Hall intended to edit the full text of the Nätyaśāstra, but abandoned the project. Apparently, Heymann also considered editing the text of the Nātyaśāstra; however, he realized that the few manuscript copies in his possession contained too many lacunae and mistakes (Rocher 1981).

3 In introductions to theatre studies, 1789 is generally cited as the year Indian theatre was discovered in Europe through Jones' translation of Kālidāsa's play, first prepared in Latin and translated into English for publication in 1789. For the history of the reception of the Śakunta$l \bar{a}$, see Figueira 1991 and Thapar 2011.

4 Wilson (1827) noticed that Indian commentators on Sanskrit plays constantly quoted Bharata's 'Sútras', or aphorisms. However, he did not really believe in the existence of a text in a complete form written by Bharata. For a recent assessment of his work, see Zastoupil 2018.

5 Regnaud published chapter 17 (vāgabhinaya) in 1880, chapters 15 to 16 (vācikäbhinaye chandovidhāna and chandoviciti) in 188o, and chapters 6 to 7 (rasādhyāya and bhāvavyañjaka) in 1884 .

6 In 1888 , Grosset published the text and translation of chapter 28 on music and, in 1898, an edition of chapters 1 to 14 . 
of Sylvain Lévi in $1890 . .^{7}$ In 1894, four years later, the first complete edition of the Nātyaśästra was published in India, in the Kāvyamālā series, on the basis of two manuscripts. ${ }^{8}$ At the end of the nineteenth century, the idea that commentaries on the Nātyaśāstra existed, but that these were irretrievably lost, was common among scholars and was accompanied by a widespread sense of regret over the lack of exegetical tools with which to understand Bharata's text. ${ }^{9}$

A new wave of studies on the Nátyaśāstra was inaugurated in the $1920{ }^{10}$ which saw the publication of new works on Indian theatre, mainly concerned with its literary and aesthetic aspects. ${ }^{11}$ In 1925, S.K. De published the first fragments of the Abhinavabhäratī, namely the whole commentary on the rasasütra from the sixth chapter. ${ }^{12}$ The second complete edition of Bharata's treatise followed shortly in Benares in 1929, in the Kashi Sanskrit Series, ${ }^{13}$ and in 1943 a third one was published in Bombay, again in the Kāvyamālā series. ${ }^{14}$ Meanwhile, Manavalli Ramakrishna Kavi was working on the edition of the longawaited commentary on the Nätyaśāstra, Abhinavagupta's Abhinavabhāratī, which came out in four volumes published in the Gaekwad's Oriental Series (GOS) between 1926 and 1964. This huge work also comprised the text of the

7 On S. Lévi's work on Indian theatre, see Bansat-Boudon 2007.

8 Initially welcomed with enthusiasm, this edition by Pandit Śivadatta and Kāśināth Pāṇdurang Parab was soon recognized as 'hasty' and 'uncritical' (Rocher 1981: 116).

9 As early as 189o, Lévi mentioned the loss of Abhinavagupta's commentary, of which he however possessed some fragments (Lévi 1963: 16), possibly corresponding to MS. SL. 55A, a manuscript now at Collège de France in Paris. See Part 2, § 4.2.2, n. 41 and 42.

10 In the meantime, two important discoveries took place, which were to influence the history of Indian theatre: the first one, in 1910, concerned thirteen new plays attributed to Bhāsa and retrieved in Trivandrum by T. Ganapati Sastri; the second, in 1911, consisted in the discovery of the fragments of Buddhist dramas in Turfan, among which was the Śăriputraprakaraṇa of Aśvaghoșa. On these discoveries and their impact on studies of Indian theatre, see Renou 1963: xviii.

11 See, e.g., Konow 1920 and Keith 1924. More titles can be found in Renou 1963: x, n. 3. Another major concern of early scholars was the question of the origin of Indian drama, on which see Bronkhorst 2003.

12 S.K. De (1925) used two incomplete manuscripts of the Abhinavabhäratī, on which see Part 2, § 4.2.1.1, n. 27.

13 Far from being critical, this edition by Batuk Nāth Śarmā and Baladeva Upādhyāya was based on two manuscripts other than those used in the Kāvyamālā edition, and also having a different chapter numbering. According to Ghosh, this text represents the longer recension of the Nātyaśāstra. On the existence of two recensions of the Nātyaśāstra, see Part 2, §4.2.1.1.

14 This improved edition of the Kāvyamālā of 1894, prepared by Kedarnatha Sahityabhusana, also acknowledges the edition of the Nátyaśāstra by Grosset and the one of the Abhinavabhāratī by Kavi. 
Nātyaśästra, edited on the basis of forty manuscripts, as claimed by its editor..$^{15}$ Following the principle according to which a text cannot be edited unless its meaning is understood (Ghosh 1967: xxiv), Manomohan Ghosh prepared a full translation of the Nätyaśāstra, which was published in two volumes in 1951 (chapters 1-27) and 1961 (chapters 28-36), along with a complete edition, whose two volumes came out in 1956 and 1967.

The publication of the first volume of the Abhinavabhäratī by Kavi in the mid-192os revived scholarly interest in the Nātyaśāstra, and inaugurated a new period of studies focused on poetics and aesthetics. ${ }^{16}$ At the same time, Kavi's publication of the reproductions of the bas-reliefs with depictions of the 108 karanas, the basic dance movements described in the fourth chapter of the Nātyaśāstra and sculpted on the gates of the temple of Chidambaram, launched a new avenue of research which engaged, beside philologists, also art historians and archaeologists, as well as theatre and dance performers. ${ }^{17}$ In the wake of this renewed interest in dance, in 1936, Naidu et al. published a translation of the fourth chapter of the Nātyaśästra, together with the reproductions of the engravings of the karanas, an introduction on Indian dance, and an appendix with a glossary of dance terminology. ${ }^{18}$

Three more editions of the Nātyaśāstra with the Abhinavabhäratī commentary saw the light of day in the last three decades of 1900. Between 1971 and 1981, Madhusudan Shastri published an incomplete edition, along with a Sanskrit and a Hindi commentary; between 1981 and 1984, R.S. Nagar prepared a complete edition of the text; and between 1992 and 1996 Parasanatha Dvivedi published a partial one together with a Hindi translation and commentary. ${ }^{19}$ A reprint of the text of the Nätyaśāstra with the Abhinavabhāratī, along with the translation by Ghosh, was carried out in recent times by Pushpendra Kumar, ${ }^{20}$ and a new English translation (the best so far) was attempted

15 On this edition and its limitations, see Part 2, § 4.2.1.1.

16 Such studies prompted a series of improvements on the edited text of the Abhinavabhāra$t \bar{t}$, through the reconstruction of problematic passages with the help of parallel sources and quotations from other texts, as for instance Raghavan 1940 for the śāntarasaprakarana, Gnoli 1968 for the commentary on the rasasütra, and Kulkarni 2003a.

17 The entanglements between editorial efforts, the revival of dance, and nationalist agendas in the same period are dealt with in $§ 1.2$. See also Ganser 2018.

18 This is Tândava Lakșanam or The Fundamentals of Ancient Hindu Dancing (Naidu et al. 1980).

19 On these editions, see Part 2, § 4.2.1.2-4.

20 This edition has the advantage of including the text and the English translation of the Nś by Ghosh, along with the text of the $\mathrm{ABh}$, but philologically it has little value. The editor does not say which text of the Abhinavabhäratī he is reproducing, though one can infer that it is the one given by Nagar. Moreover, the work is scattered with printing inaccuracies. 
by N.P. Unni and published in four volumes in 1998, with a voluminous introduction and notes based on the Abhinavabhäratī. ${ }^{21}$ The first volume of the longawaited new critical edition of the Nätyaśāstra (chapters 1-14) was released in 2015 by K.D. Tripathi. It incorporates previously unpublished manuscripts from Jaipur and Nepal, the latter of which are probably the oldest available manuscripts, as they bear colophons replete with dates and details about the scribe.

The existing translations of the Nâtyaśāstra are useful tools for reference when one wishes to get an overview of the various topics dealt with in its thirtysix or thirty-seven chapters. ${ }^{22}$ Yet these translations do not help in making the text intelligible when it comes to the technical passages or to the technical terminology, which is left untranslated in most cases. The lack of exegetical tools to understand the Nätyaśāstra was deeply regretted by those who first attempted to edit the text. Once the text of the Abhinavabhāratī became available, it was soon recognized that-besides the numerous infelicities of Kavi's edition-Abhinavagupta's commentary could not be of much help in making Bharata's text more transparent (Rocher 1981:126, n. 44). As Ghosh stated in the introduction to the second volume of his translation, the Nātyaśāstra must very early on have become a text incomprehensible to most, and certainly some of its portions were not intelligible even to an attentive reader and connoisseur such as Abhinavagupta:

The very complex dramatic-cum-musical art described in the present work appears to have become obsolete more than one thousand years ago. The text of the Nātyaśästra was handed down not because professional actors needed it, but because it was considered a Veda, the Nätyaveda, and as such worthy of being saved from extinction. Hence the work was

21 This translation underwent a second revised edition in 2014. As the author states in the introductory volume, he followed the Sanskrit text adopted by K.P. Narayana Pisharoti for the Malayālam translation of the Nātyaśāstra, which made use of one independent palmleaf manuscript (most probably from Kerala), apart from three editions (Unni 2014: 14). Two more translations are worth mentioning for the sake of comprehensiveness, although they do not make any critical use of the manuscripts and in many cases provide only a paraphrase or a summary of the contents of Bharata's text. The first is a translation by an unspecified Board of Scholars, published in Delhi in 1989; the second is the one by A. Rangacharya of 1996. On other translations in various Indian regional languages, see Unni 2014: 13 .

22 The numerous differences in the verse numbering and chapter divisions, added to the breadth of textual materials, make any attempt at simultaneously using the various editions and translations unnecessarily slow. 
somehow preserved. But in the absence of a living tradition, it does not yield a full view of the complex art.

GHOSH 1961: v

Louis Renou, on the contrary, was not much troubled by the fact that even the commentary of Abhinavagupta could not cast light on the difficult passages concerning artistic practice, as he understood the Abhinavabhäratī to be of special interest for the history of ideas, rather than for understanding theatrical practice (Renou 1963: xxix). By downplaying the value of Abhinavagupta's commentary to the history of theatrical practice, however, one of its most important functions for the modern reader is missed. Thanks to the Abhinavabhāratī, in fact, one is able to trace some of the important developments that the performative traditions underwent in the classical and medieval period, and at the same time to follow the intellectual debates that went along with those changes. This twofold focus on theory and practice should no doubt encompass the period ranging from the composition of the Nätyaśāstra to that of the Abhinavabhäratī, but also the much understudied period of Indian pre-modern history in which these texts were copied, transmitted, quoted, rewritten, epitomized, etc.- -all textual practices that guaranteed their preservation to the present day.

The editorial enterprise leading to the edition of the Nātyaśāstra, with its history of almost 15 o years, was marked by an initial concern with the literary texts of the plays, combined with an interest in the textual form of the 'Treatise on Theatre.. ${ }^{23}$ As mentioned above, it was with the publication of the first edition of the Abhinavabhāratī, which included reproductions of the images of the dance movements of the Nätyaśāstra (the karanas) carved into the gates of the Natarāja temple in Chidambaram, that this text received the attention of a new and larger public. For the first time, a direct link was being traced between Bharata's text, the sculpted images of dancers and musicians populating the temples of India, and the living traditions of dance. The efforts of those who undertook to edit and translate the Sanskrit texts on dramatic theory and the

23 As Vatsyayan (1989) has pointed out, Indian editors first directed their attention to the Nātyaśästra owing to its similarity to other known normative texts, for instance the Mãnavadharmaśāstra. The most blatant case is that of P.V. Kane, who in 1923 published a very influential History of Sanskrit Poetics. 
performing arts were greeted with enthusiasm by supporters and promoters of the so-called 'revival' of Indian dance and music, a reform movement that started in the $1930 s .{ }^{24}$ As the Nātyaśästra is part of this entangled history, it might prove fruitful to set its reception in this wider context.

Even prior to the publication of the dance bas-reliefs accompanying the text of the fourth chapter of the Abhinavabhärati in the Gos edition of 1926, the English translation of a short Sanskrit treatise on dance and histrionics had been circulating in India, Europe, and the United States. This is The Mirror of Gesture, a translation of Nandikeśvara's Abhinayadarpana ${ }^{25}$ that was released as early as 1917 by Harvard University Press, a collaborative enterprise between Ananda K. Coomaraswamy and Duggirala Gopalakrishnayya. ${ }^{26}$ Coomaraswamy had been particularly concerned with establishing the significance and function of his text for a Western readership, including actors and dancers, but never hinted at its possible adoption by an Indian reader or performer. His translation was in fact the direct outcome of a long-standing confrontation with a certain Western critique of Indian art, and of an endeavour to tame cross-cultural encounters with Indian art by setting an ideal standard for the original and authentic in the form of what was textually based. ${ }^{27}$

At the same time as the demand for accessing Indian art treatises increased among 'Western' artists and critics fascinated by the 'East', Indian theorists had

24 For a comprehensive bibliography on the subject, see the very informative introduction in Peterson \& Soneji 2008. On the recovery of Sanskrit texts on dance in this period, see Ganser 2018.

25 The date of composition of the Abhinayadarpana is highly uncertain. Hypotheses range from the fifth to the thirteenth centuries $\mathrm{CE}$, but it might be even later. A group of passages from this text found, with slight changes, at the beginning of the seventh chapter of the Samgitaratnākara has raised doubt about the relative dating of these two texts. Following Alain Daniélou, Ghosh (1957:31) and Bose (2007) maintained the priority of the Abhinayadarpaṇa on the basis of the identification of its author Nandikeśvara with writers quoted in earlier texts, while Kunjunni Raja has cast doubt on the direction of the borrowing in his preface to the translation of the dance chapter of the Samgitaratnākara (Kunjunni Raja \& Burnier 1976: vi-vii), a position I also share (see Ganser 2018: 91, n. 3 and Ganser 2021).

26 See Coomaraswamy \& Gopala Kristnayya 1936. The Abhinayadarpana was translated anew by Manomohan Ghosh in 1934, together with a critical edition of the Sanskrit text. This treatise became very popular among dance practitioners, and it is still used by contemporary artists, especially, but not exclusively, in the training of Bharatanatyam. For a discussion on the use of the Abhinayadarpana in dance practice, see Ganser 2011, and on the entangled history of The Mirror of Gesture, see Ganser 2018.

27 As I demonstrate in Ganser 2018: 104-113, this matches the concerns of the English dramatist and theatre critic E. Gordon Craig, who was the instigator of and main interlocutor in Coomaraswamy's translation of the Abhinayadarpana. 
to cope with a more pressing criticism of dance and the performing arts coming from within India. This criticism took the name of the 'Anti-Nautch Movement'; it was launched at the end of the nineteenth century by English missionaries and Indian social reformers, and embraced at the beginning of the twentieth century by the new elites close to colonial power. ${ }^{28}$ Its aim was to eradicate dance from both temples and public venues. The critique revolved especially around the sexuality of the ritual dancers and the dedication of minor girls to the temples. ${ }^{29}$ This led not only to the stigmatization of dance and the social groups traditionally associated with it, but also to concrete provisions and legislative acts against them, which profoundly transformed the social landscape of the performing arts. ${ }^{30}$

One of its major consequences was the displacement of the dance tradition from the custody of its hereditary exponents to a new middle class of Brahmin performers. The latter took up the task of reviving (or better, reforming) the older practices, which involved the spatial relocation of dance from the temple premises to the theatre stage, and called for major revisions to the dance repertoire. ${ }^{31}$ This prompted the necessity to recover Sanskrit texts on dance and music, through which imaginative links with the past could be forged, together with authoritative claims of pedigree. Against this background, the two texts that assumed foremost importance were the Nātyaśästra and the Abhinayadarpana. Through the act of voluntary oblivion of its geographical and historical origin, South Indian dance was renamed with the Sanskritic name 'Bharatanatyam', recalling Bharata's text, and its technique was re-codified with the help of the Abhinayadarpana, assisted by the practical instruction of the hereditary dance teachers who were called to participate in the revival. ${ }^{32}$ Within the larger effort of the 'Sanskritization' or 'textualization'

28 The term 'nautch' is the Anglicized form of the Hindi word $n \bar{a} c$, and was used especially in nineteenth-century accounts to denote dancing in general. See, e.g., A. Srinivasan 1985.

29 The criticisms lodged towards dance and music did not concern only the performing arts, but also Indian culture and civilization at large, and elicited manifold responses at different levels. See, e.g., Ali 1999.

30 The Anti-Nautch Movement culminated in a law, passed in 1947, which aimed at abolishing the dedication of the devadāsiss. On the decline of traditional performers coming from a Devadāsi lineage, and on their gradual disappearance from the contemporary dance scene, see, for instance, Gaston 1996. The most comprehensive study on the Devadāsī system and its history is still Kersenboom 1987.

31 Nowadays, scholars prefer to speak of 'reform' instead of 'revival' and of 'reformed' practices, as these also involved a shift in the social status of the performers, which went together with the effacement of any reference to erotic themes in the repertoire.

32 The most blatant case of the use of Sanskrit texts as authoritative predecessors in the construction of a new tradition of Indian dance is that of Rukmini Devi, a Brahmin woman 
of dance, ${ }^{33}$ the work of editors of Sanskrit texts and of scholars working on the history of dance, such as V. Raghavan, were fundamental to providing the newly reinvented dance traditions with a theoretical background and a continuity with the classical past, expressed in the Sanskrit texts and illustrated in the refined dance sculptures.

The texts pleaded for the antiquity of the dance, and the sculptures provided continuity with the temple tradition, temporally relocated to a mythical ancient past. ${ }^{34}$ Prior to the publication of the images of the karanas in the Gos edition of 1926, the same illustrations had been published by the Government Epigraphical Department in the Madras Report of 1914, in a somewhat partial and reshuffled order, which was reproduced by Kavi and successively by Naidu et al. Only in the second, revised Gos edition of 1956 did K.S. Ramaswami Sastri restore the order of the complete set of 108 karanas represented in the basreliefs of the eastern gopura of the Chidambaram temple, matching them with the corresponding Sanskrit verses from the Nätyaśāstra inscribed below the figures in Grantha script. ${ }^{35}$

Apart from pointing out these discrepancies in matching the text with the images, Ramaswami Sastri explains that Kavi used the verses of Saarngadeva's Samgitaratnākara for reconstructing the missing commentary on some of the karanas, of which the Saṃittaratnākara offered a versified rendering. Śārngadeva's verses on the karanas were also added by Ramaswami Sastri to an appendix of the volume, 'in order to facilitate those who are interested in the study of Karana literature, which is as essential for a study of Bharata-Nātya as alphabets and words are for study of a language' (Ramaswami Sastri 1956: 33). These remarks on the prospective use of the descriptions of the karanas in the Nātyaśāstra are revealing with regard to attitudes and biases towards Sanskrit texts on dance in this period. They also provide information about the expected readership of such publications. Similarly, the attitude of Naidu is best illustrated by his translation of the title of the Nātyaśāstra as 'The Science

from Madras, married to a member of the Theosophical Society. Rukmini Devi learned the art of dance from Devadāsī masters and started to perform publicly on the modern stage in the mid-'3os. On Rukmini Devi, see Meduri 20o9.

33 By the process of Sanskritization in relation to the performing arts, scholars are generally referring to the 'approximation to the norms of the elite paradigm, especially by invoking the authority of Sanskrit texts' (Peterson \& Soneji 2008: 13). On the Sanskritization and textualization of Indian dance, see Ganser 2021.

34 A good introduction to dance traditions and sculpture is Guzman 2001.

35 On the question of the images of the karanas, and for a map of their positions in the niches of the four portals of the temple of Națarāja, see the preface to the second edition of the Abhinavabhārat̄̄ in Ramaswami Sastri 1956: 33-5o. 
of Dancing' (Naidu et al. 1980: 1). Naidu speaks of the 'evil days' and the 'oblivion of the art of dancing' due to its 'misbehaving exponents', while at the same time spotting signs of hope in what he dubs a 'general artistic renaissance' taking place in India, within which he situates the 'revival of classical dance' (ibid.: 16).

A new wave of scholarship on the karanas was inaugurated by Kapila Vatsyayan and Padma Subrahmanyam in the 196os, at a time when the social movements that had accompanied the revival of dance largely lost their vitality. ${ }^{36}$ In her two books devoted to 'Indian classical dance', Kapila Vatsyayan (1974 and 1977) uses the Sanskrit treatises to single out some key concepts that, in her eyes, represent the essence of what could be regarded as 'classical', a label that becomes opposed to the 'folk'. The canons of classicality established on the basis of these treatises were tested against existing forms of dance, such as Bharatanatyam, Odissi, Kuchipudi, Kathak, and so forth, which accordingly came to be recognized as 'classical'. The subject of the karana sculptures in Chidambaram and their link with the Nätyaśāstra is dealt with at length in Vatsyayan 1977: 106-154, and was later supplemented by a study of the karanas sculpted on the outer walls of the temple of Sarangapani in Kumbakonam, Tamil Nadu, in Vatsyayan 1982. The karanas, she suggests, have to be evaluated in terms of cadences of movement and not as static poses, as previous scholars had done: 'Obviously the plastic can capture only a single moment in a continuous flow of movements and only suggests through the arrested image the moment before or after' (Vatsyayan 1974: 5). The recognition of the primacy of kinetic movement in dance sculptures could, according to the author, provide a new and more effective methodology for the identification of the sculptural and textual evidence.

A similar claim of methodological innovation in the study of karanas was made by Padma Subrahmanyam, a dance performer and scholar whose research focused on the study of the karanas in texts and sculptures, as well as in the practical reconstruction of what she deemed as the dance described by Bharata in the Nātyaśāstra (Subrahmanyam 2003) $\cdot{ }^{37}$ Subrahmanyam's methodology consists in comparing the textual descriptions and the sculptural depictions by considering the latter as snapshots in a given string of movements, and therefore liable to differences of representation based on the respective portions of the movement captured. The same method had been

$36 \quad$ For an account of the different agendas and methods in Vatsyayan's and Subrahmanyam's interpretations of the karanas, see Lopez y Royo 2004.

37 For a brief account of Subrahmanyam's career as a scholar and artist, see Iyer 1996, especially n. 2 and 7 . 
adopted by Alessandra Iyer to prove that the depictions of dance in the temple of Prambanan in Central Java were also illustrations of the karanas of the Nätyaśāstra. She further suggested that a dance tradition issuing from Bharata's text must have existed in Central Java by the early ninth century (Iyer 1996, 1998a, 1998b), an approach that was criticized in reviews of the book, as it was felt that the Prambanan sculptures were not well enough preserved to corroborate their identification with the textual descriptions of the Nätyaśāstra. Moreover, the claim that a living tradition had to be posited as the model for the karana depictions was seen as particularly problematic, since sacred imagery does not necessarily imply empirical inspiration, but only a transfer of technique or knowledge of iconography (Hughes-Freeland 1998: 78).

The greatest merit of the 'new' formulation of the kinetic dimension of the karanas is, in my opinion, precisely the fact that we do not necessarily need to postulate a living dance tradition-based on the text of the Nätyaśāstra but interpreted regionally - to explain the differences between the various poses in the dance sculptures accompanied by Bharata's verses. It is possible that the sculptors had simply read and interpreted the definitions of the karanas differently. In her avowed effort to 'revive a lost dance technique' (Subrahmanyam 2003: iii), allegedly still practised in ancient and medieval India (if not also in Indonesia), Padma Subrahmanyam took it for granted that the Nātyaśāstra had been used as a practical manual. She therefore proceeded to compare Bharata's way of dealing with body movement with the training employed by contemporary dance masters, finally bringing her point home: contemporary forms of dance are based on a Sanskrit text different from the Nātyaśāstra, namely the Abhinayadarpana, while her own reconstructed practice, closely based on the Nätyaśāstra, displays a greater degree of authenticity (Subrahmanyam 2003: iii).

More realistically, Bose put the question of the relationship between modern and ancient practices in the following terms:

Since the rebirth of informed interest in dancing in early twentieth century, its antiquity has been acknowledged but precisely what the art was in antiquity remains unclear.

BOSE 2007: 1

Bose's proposed methodology for tackling dance history consisted in analyzing the technical terminology of dance throughout all the published Sanskrit texts on the subject, and acknowledged the necessity of determining a chronology for this textual corpus in order to detect the changes and developments that the artistic tradition underwent. Her claim is that 'following these changes 
through treatises is essential to a historical investigation because not only do theoretical discussions in the texts reflect dancing as it was but the practice of dancing in turn seems to have followed the precepts laid down in the texts' (Bose 2001: 45). According to such a principle that texts reflect and inform the practice, Bose concludes about the Abhinayadarpana:

Judging by the author's concern with performance, it seems quite likely that this text was meant as a practical guide to be used by a dancer to learn the technique of dancing. This is indeed how the text is used today in at least one classical style of Indian dancing, namely, Bharatanatyam, although practitioners of this style claim that it is named after Bharata. $[\ldots]$ They are the true followers, they claim, of the technique that Bharata recorded. But on analysing the technique in which they actually train we find that it does not derive from the Nātyaśāstra, but from the Abhinayadarpana.

ibid.

While it is undeniable that the Abhinayadarpana informs dance practices today in several ways, it is not certain whether this and other texts on dance were initially conceived as pedagogical tools for the dancers to learn the technique.

The fact that Nandikeśvara's text was the first treatise on dance to receive a translation into a European language might partly justify its great success and its successive adoption by generations of dancers across the world. Yet recent studies in dance history have also shown that translations in Indian languages and vernacular adaptations of this text had started to circulate in the regions corresponding to modern Tamil Nadu and Andhra Pradesh already in the nineteenth century, under the influence of the court of Thanjavur. ${ }^{38}$ Such a wide and diversified regional textual production was to be obscured, to some extent, by the immense success of the Abhinayadarpana and its wider dissemination through English translation, as well as by the great status assigned to the Nätyaśāstra of Bharata. Yet the existence of many earlier translations and vernacular adaptations of the Abhinayadarpana suggests that this text was indeed an important source for more than one reason, and that for performers it was considered a more useful and handy manual than the Nātyaśāstra, despite the latter's status as a seminal śāstra.

38 On the multilingualism of textual production on dance at the court of Thanjavur in the Maratha period, see Krishnan 2008, Peterson 2011, Soneji 2012: 27-69, and Ganser 2021. 
The image we have today with respect to the written production on Indian dance and its regional transmission is still very partial, and the dynamics of the interaction between texts and practice poorly understood. The first studies on dance were mainly concerned with the recovery of the textual tradition linked with the Nātyaśâstra in order to provide authoritativeness to the performing arts that were undergoing complex processes of reform and relocation, as well as to create links with the past and the idea of a continuous tradition. As a result, a certain tendency to relate the texts to the living traditions in a one-to-one relationship has prevailed, and still proves to be an irresistible paradigm even in otherwise very valuable studies. ${ }^{39}$

\subsection{The Nātyaśāstra and the Place of Dance}

The Nātyaśāstra is the oldest and most complete extant work on dramatic art in India. Its encyclopaedic character makes it a seminal text not only in dramaturgy and poetics, but also in an array of allied subjects and ancillary arts, including music and dance. Despite its fortune as a foundational text - testified by an almost unchallenged authority imposed on it by all later writers on related topics and by the enormous amount of scholarship devoted to it- there is little consensus, within and without the tradition, about its composition, authorship, and date. The main scholarly positions on these three connected issues will be presented below, and discussed in the light of the narrative structure of the treatise and the position of the chapter on dance within its narrative.

\subsubsection{Composition, Authorship, and Date}

As we know it in its extant form, the Nātyaśästra presents itself as a text in thirty-six or thirty-seven chapters (or thirty-five in the recently edited Nepalese manuscripts, on which see Tripathi 2015) of various lengths, arranged within a narrative frame and composed mainly in verse, with occasional prose passages. ${ }^{40}$ Traditionally ascribed to the mythical author Bharata, who is credited

39 The present overview of the major approaches to textual and visual evidence on dance is obviously not meant to be exhaustive. Among studies on dance, see also Sivaramamurti 1974 and Gaston 1990, and on the tradition of performing the karanas, see LégeretManocchaya 2017. Beside studies dealing with the textual past, a number of valuable contributions based on the living, observable practices are gaining momentum in scholarship on dance by incorporating methods from the social sciences.

40 A number of general introductions on the text and contents of the Nātyaśāstra are available. See, for instance, Ghosh $195^{1}$ and 1967 , as well as Vatsyayan 1996. For a detailed bibliography on the Nätyaśāstra, see Cahill 2004, sub voce. 
with the introduction of dramatic art among humans, the Nātyaśāstra ('Treatise on Theatre') belongs to the genre of the scientific treatise, the śästra, and is devoted to the topic of nātya, as its title suggests. ${ }^{41}$ The semantic spectrum of the term nătya is broader than its English equivalents 'drama' or 'play', since it encompasses both the play in its literary form and the spectacular object, carried out through a codified acting protocol accompanied by music, songs, and dance, and preceded by a preliminary rite performed on stage. It could be best translated with the word 'theatre', provided we have in mind a sense close to the one assigned to this term by Schechner. ${ }^{42}$

The breadth and variety of the topics dealt with in the Nätyaśāstra has led many scholars to consider the present text as resulting from a process of incorporation of disparate materials over a long period. The existence of Națasütras ('Aphorisms for the Actors') attributed to Śilālin and Kṛsaaśśva by Pāninini (Aștādhyāȳ IV 3.110-111) points to a previous tradition of scientific writing on theatre, possibly also including dance, which might have been partly incorporated into Bharata's text. Furthermore, the mixed style of the text has been adduced as evidence of its multilayered nature. To a majority of verses in anuștubh metre, a few verses in âryā or upajāti are added, as well as a few but sometimes extensive prose passages in the sixth and seventh chapters. Certain ślokas and $\bar{a} r y \bar{a} \mathrm{~s}$ are indicated in the text as ānuvam śya ('traditional'), and other verses are given as quotations without specifying their sources. ${ }^{43}$ What is more, in chapter 6 it is suggested that the text contains a structure of sütras (aphorisms), bhässya (prose commentary), kārikās (versified aphorisms), and niruktas (traditional etymologies). This challenging puzzle has made way for a variety of scholarly accounts and hypotheses about the composition of the Nätyaśästra. ${ }^{44}$

41 See my remarks in the Introduction above on śāstra as a textual genre.

42 Schechner (1973: 8) assigns to 'drama' the meaning of written text or score, to 'script' that of the basic code of the event, and to 'theatre' the concrete event as enacted by a group of performers. The last term is the broadest, and encompasses the first two. To these three an even more encompassing word is added, that of 'performance', which describes the whole constellation of events taking place between audience and performers. Thus drama is the domain of the author, script of the teacher, theatre of the performers and performance of the audience. Although the Nātyaśāstra also includes the dimension of the audience, hence of performance, the audience is not the primary recipient of the text and its teachings, which are mainly aimed at the first three categories. Moreover, the term 'performance' is not unambiguous, since Schechner assigns it equally to non-dramatic spectacles.

43 According to Abhinavagupta, some of the āryās were not composed by Bharata himself, but taken from other authors. The ānuvamśýaślokas, in their turn, are considered to be verses handed down traditionally, hence also incorporated from pre-existing sources.

For a long but non-decisive argument on the composition of the Nātyaśāstra, see Sriniva- 
The question of the unitary nature of the text opens up the closely connected issue of its authorship and date. Within the indigenous tradition, some comparatively late Sanskrit works make a distinction between two different figures, Bharata and Ādibharata or Vṛddhabharata, and two different epitomes of the treatise, a longer work in twelve thousand verses and an abridgement of it in six thousand verses. The latter would be nothing but the Nätyaśāstra as we know it today. ${ }^{45}$ The distinction of more than one author of the text usually goes hand in hand with the belief in a distinct authorship for the versified and prose portions of the treatise. Moreover, the dialogical scene at the opening of the treatise, where Bharata is referred to in the third person, has raised doubts about authorship even within the tradition. According to its major commentator Abhinavagupta, however, the Nätyaśāstra is a unitary text in thirty-six chapters and six thousand verses composed by an exceptional individual called Bharata. ${ }^{46}$ In modern studies, the idea that the Nātyaśästra could be ascribed to a single author found a strong supporter in Vatsyayan, who stressed its unity of structure and purpose, and its furthering of a 'single integrated vision' (Vatsyayan 1996: 6). But even when looked at as a single work with an authorial (or editorial) intention, there is no doubt that the text incorporates older materials and that it was subject to additions and interpolations. Moreover, the great

san 1980. Srinivasan does not subscribe to the accepted view of a composition consisting of subsequent historical accretions, but claims that the text was heterogeneous from its origin, and that its various parts were put together despite their mutual incoherence. However, his conclusions are based on the analysis of partial portions of the texts, namely the sixth and seventh chapters. Looking at the complex prose-verse structure in the sixth chapter, S.K. De (1960: 24-31) argues for a stratification of the text and assigns the different styles to different stages of the work (kārikā, prose, sūtra-bhāșya, and again kārikā). For a study of the terms sūtra, bhāssya, and kārikā in the Nātyaśāstra, see Varma 1958, and for an updated look at the question, see Radicchi 2001.

This opinion is expressed, for instance, in the twelfth-century Bhāvaprakāśana of Śāradātanaya. For the mention of Ādibharata and Vrddhabharata in different texts and for a summary of arguments for a split authority for the Nātyaśāstra, see Unni 2014: 16-21. As noticed by Olivelle, among others, in his introduction to the Mānavadharamaśāstra, 'the motif of a large treatise composed in illo tempore and subsequently abridged for the use of humans is a recurrent one in Indian literature' (Olivelle 2005: 19, n. 24). Instances of similar narratives of textual origin and history are found in the Mahäbhärata, in the Kämasūtra, and in various texts on Âyurveda.

46 The arguments about the unitary nature of the Nätyaśāstra, presented in the form of objections and answers to the question of the authorship of the five questions at the beginning of the Nātyaśāstra, are presented in ABh ad Nś 1.6, vol. 1, pp. 8-9, with the concluding words that 'the true essence [of theatre] is established by the treatise in form of a great sentence of six thousand verses' (mahāvākyātmanā șațsahasrīrūpeṇa [...] śāstrena tattvam nirnīyate). 
disparity in the number of verses and their arrangement into chapters as we find them in the extant manuscript copies pleads for a complex and non-linear transmission, which must have altered the original composition to a greater or lesser extent. All these factors must be borne in mind in assessing the date of the Nātyaśāstra. ${ }^{47}$

As is the case with most ancient Indian texts, the date of the Nātyaśāstra is uncertain. In considering the matter of dating, Kuiper (1979) concludes that most scholars agree on the first or second century CE as the period when the older parts were redacted; M. Ghosh, however, assigns the text to 5 Оо ВСЕ. ${ }^{48}$ Lévi (1902) assigns it to the third century CE, since according to him the occurrence of certain words and titles would place the text in the Scythian Kșatrapa period. Sircar (1974: 22-23), on the contrary, considers it a work of the Gupta age not much earlier than the fifth century, based on the comparison of some of the toponyms and other names in the Nătyaśästra with inscriptional evidence. On the whole, scholarly opinions on dating tend to reiterate the view that the text was composed through successive incorporations. It is generally accepted that, in a relative chronology, the testimony of Kālidāsa (4th-5th c.?) should be considered decisive for the upper limit of the Nätyaśāstra in the structure we are familiar with today, since the celebrated Gupta poet and dramatist mentions the name of the work and its author in two of his plays, the Mälavikāgnimitra and the Vikramorvaśíy $a .{ }^{49}$ But there is little agreement about its priority or pos-

47 As Lidova (1994: 2) puts it, 'we can't limit the dating problem to the question when the extant version emerged. Its multilevel text and the dates based on cultural historical information, provided by the treatise are separated by more than a millennium, from

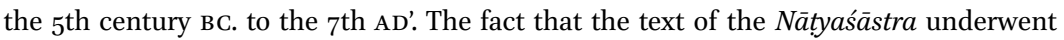
much redactional activity is reflected in Abhinavagupta's commentary, in which other commentators are referred to with respect to additional verses, alternative readings, and divergent ordering of the verses. According to Pollock (2016: 47), the text was clearly reedited, and partly rewritten in Kashmir around the eighth or ninth century CE, at the time when it also first received commentarial attention from Udbhața.

48 Through a consideration of internal evidence, M. Ghosh arrives at a date between 100 BCE and $200 \mathrm{CE}$, which he later reconsiders, pushing it further back to the fifth century BCE. Following Bharata's translator, B. Gupt (1986-1987) assigns the text to the fifth century BCE. The arguments in favour of such an early date are nevertheless unconvincing. For a detailed summary of the scholarly debate on dating, see Kuiper 1979: 119-120, n. 44.

49 Kane (1971: 20-22) maintains that the chapters containing the legendary account of the genesis of dramatic art were composed later than the bulk of the technical chapters, i.e. towards the middle of the fourth century $\mathrm{CE}$, that is, immediately before the time of Kālidāsa, in order to raise the status of dramatic art. As to Kālidāsa, he quotes a 'Treatise on Theatre' or a 'Theory of Theatre' (nātyaśāstra) by name in the Mālavikāgnimitra (prose after 1.15: deva prayogapradhānam nāma nātyaśästram 'Majesty, the "Theory of Theatre" has performance as its main component'), and the sage Bharata as the theatre instructor in 
terity to the dramatists Bhāsa and Aśvaghoṣa: while scholars generally concur that Bhāsa (3rd c. CE?) knew and followed the Nātyaśāstra in composing his plays, ${ }^{50}$ a further lowering of the upper limit to Aśvaghoșa (2nd c. CE) has not been settled. ${ }^{51}$ As for its lower limit, the Nätyaśästra is considered posterior to Pānini (4th-5th c. BC) and the Națasūtras.

Although the precise date of the Nātyaśāstra is not crucial to the present study and is still open to further scrutiny, the question of composition becomes relevant as far as the place of dance in the Nätyaśästra is concerned. In the textual economy of the Nätyaśästra, in fact, dance is dealt with mainly in the fourth chapter, which belongs to the bulk of chapters (chs. 1-5) that were, according to Kane, added to the original textual core at a later point in time. ${ }^{52}$ Were this actually the case, the text of the Nătyaśāstra would initially have been conceived as devoid of a codified technique for dance, possibly reflecting a feature of dramatic performance that is implicit in the fourth-chapter narrative on the introduction of dance into the preliminary rite. This view, however, introduces more problems then it solves. How can we justify, for instance, the presence of verses containing a large amount of technical terminology proper to dance, for instance the group of nrttahastas (hand ges-

the Vikramorvaśíya (2.17, muninā bharatenayah prayogo, bhavatīṣv aștarasāśrayo niyuktah | lalitābhinayam tam adya bhartā, marutāṃ draștumanāḥ salokapālạ̣ || 'Indra, together with the guardians of the quarters, has set up his mind today to see the performance taught to you by the sage Bharata, which is based on the eight aesthetic emotions and where the acting is graceful'). In the Kumārasambhava and the Raghuvamiśa, there are also references to certain chapters of the Nätyaśāstra. Cf. Kumärasaṃbhava 7.90-91, 7.95, on which see Kane 1971: 21; Bansat-Boudon 1992: 279, n. 43; and Raghuvaṃśa 19.36, quoted in BansatBoudon 1992: 356, n. 342.

$5^{\circ}$ If Tieken's (1993) reassessment of Bhāsa's plays as belonging to the post-mid-seventhcentury Pallava court is correct, Bhāsa's knowledge of Bharata would be beyond doubt.

$5^{1} \quad$ For arguments for and against Aśvaghoșa's acquaintance with the Nätyaśāstra, see Keith 1924: 81-83. The date of Aśvaghoșa has been assigned to the Kușāna period, precisely in the epoch of the emperor Kanișka (first decades of the 2nd c. CE), on which cf. BansatBoudon 2007: 55-56, n. 9 o.

52 According to Kane 1971: 22-23; 27 , this addition was meant to elevate the status of dramatic art, opinion of which had suffered in the period of the Dharmasūtras and the early Smrtis, by endowing it with a narrative of divine origin. Accordingly, Tieken pointed out that 'a problem in Nátyaśāstra is the relationship between the main part of the text and the first five chapters. The first five chapters describe the divine origin of drama, the construction of the theatre, the consecration of the stage, the origin of the incorporation of dance in drama, and the preliminary rituals of a performance. As chapter 6 begins with a table of contents of what follows [the nattyasamgraha], the authenticity of the first five chapters has in the past frequently been questioned' (Tieken 1998: 172, square brackets mine). 
tures for dance) described in the ninth chapter, that is in a chapter subsequent to the fourth but allegedly part of the original composition? As I will argue, I think it is more reasonable to consider the Nātyaśästra as a systematization of diverse materials, issuing from pre-existing artistic traditions-which were possibly already endowed with some kind of textual or oral codification-but deliberately launched as a foundational work. This intentional, coherent, and well-planned unitary structure was conceived by a single author, or by a single editor-in-chief, called Bharata, in order to refer to an illustrious line of predecessors or to a certain class of actors. ${ }^{53} \mathrm{~A}$ closer look at the narrative structure of the Nātyaśāstra and its main junctures within the context of similar narratives may help in clarifying this position.

\subsubsection{Narrative Structure}

It is a well-known fact that many ancient texts beside the Nātyaśästra present their subject matter embedded within a mythological narrative frame. Within the literature of Brahmanical law (Dharmaśāstra), Olivelle describes the fact that the Mānavadharmaśāstra 'set his text within a narrative structure that consists of a dialogue between an exalted being in the role of a teacher and others desiring to learn from him' as a major innovation with respect to the earlier Dharmasūtras (Olivelle 2005: 25). Similarly, the whole Nātyaśāstra is presented as an answer to the questions of a group of sages (muni, rși) led by Âtreya who, eager to learn about theatrical art, approach Bharata and induce him into teaching. This setting corresponds to the outermost narrative frame, comprised of the dialogue between Bharata and the sages, which encloses the story of the origin and transmission of dramatic art, unfolding in the first five chapters and brought to a close in the last two chapters. ${ }^{54}$ Analogously to the Mānavadharmaśästra, the Nätyaśāstra presents a textual history of itself, using different narrative levels as a device. ${ }^{55}$ In it, we learn that the ultimate authority on nătya and real author of the Nātyaveda ('The Veda that is Theatre') is

53 Besides being connected to the celebrated lineage of the Mahäbhärata, the name Bharata is found in legal texts such as the Mānavadharmaśästra, in the Arthaśāstra, and in the Amarakośa, where it designates an unspecified class of performers, along with other terms such as nața, śailālin, śailūṣa, krśáásin, etc. See Iravati 2003.

54 Depending on the edition, the end of the narrative can cover chapters 36 and 37 (as in the GOS), or just chapter 36 in the editions where the two chapters are combined (in the edition by Ghosh for instance). See Ganser \& Cuneo 2012: 98, n. 22.

55 For a narratological approach to the much more complex narrative structure of the Mahābhärata, using the terminology coined in Bal 1985 and borrowed here to a limited extent, see Malinar 2005. 
in fact Brahmā, while Bharata is just the human recipient and intermediary between the divine knowledge and the human performers, fictionally represented as Bharata's own sons. ${ }^{56}$

The narrative begins in the first chapter of the Nātyaśāstra with the account of the circumstances that led to the creation of theatre. These events-which form part of the story embedded in the overarching dialogue frame-are set at the beginning of the Silver Age, an epoch of decadence in which men are no longer able to distinguish the good and right (dharma) from its contrary (adharma), since they have no access to sacred knowledge through the Vedas. ${ }^{57}$ In order to bring this situation to an end, the gods headed by Indra approach Brahmā and ask him for an object of diversion (krïdanīyaka) that would be both visible as well as audible (drśyam śraryam ca). Absorbed in meditation, Brahmā creates a Fifth Veda, namely theatre (nätya), by assembling its various components from the four canonical Vedas: dramatic text (pāthya) from the Rgveda, songs (gìta) from the Sâmaveda, acting (abhinaya) from the Yajurveda, and tastes (rasa) from the Atharvaveda. Asked to put it into practice, the gods suggested handing it over to humans, whom they considered more apt to the task. That is how Bharata comes to be the first human being to receive instruction in dramatic art and to put it into practice. He in fact transmits the knowledge of theatre to his sons, the actors, and is eventually asked to get ready for a performance. First the play is presented to a divine audience during the festival of Indra's banner, the Indradhvajamaha. At that time, a group of hindrances (literally, the vighnas) interfere, disturbing the performance to the point that it becomes necessary to build a playhouse so as to ward them off. Various deities are appointed to the different areas of the stage and the theatrical building for the protection of the actors. At the end of the first chapter, the practice of worshipping the deities of the stage (rangadaivatapujjana) is also instituted. Two accessory chapters follow, in which the minute details of the construction of the playhouse (ch. 2) and the rites of consecration of the scenic space (ch. 3) are laid down. These chapters form a sort of digression with respect to the narrative of the origin of theatre: they are pedagogical in character and, beyond the technical instructions, do not contain any narrative material.

$5^{6}$ According to Olivelle, the tradition of presenting a text as a dialogue in which a teacher instructs a pupil, a son, or a king goes back to the Brähmanas and the Upanișads, while the transition to divine instruction can be traced to the Chāndogya Upanișad. Even Buddhist literature might have played a role in the creation of similar kinds of narratives, on which see Olivelle 2005: 27 .

57 This corresponds to the second epoch, the tretāyuga, in the well-known system of the four ages (yuga), progressively deteriorating in a cyclic fashion: krta, tretā, dvāpara, and kali. 
The embedded narrative of the origin of theatre proceeds in the next chapter, the fourth, in which Bharata and the actors are asked by Brahmā to prepare for another theatrical performance, this time to be presented to Śiva. After watching the performance, Śiva suggests that dance should be introduced in the 'preliminary rite' (pürvarainga), which now precedes the play, so as to make it variegated. ${ }^{58}$ An explanation, technical in character, of the basic units of dance is also found in this chapter, as well as instructions for the application of dance to the musical segments of the pürvaranga. Complete details of the performance of the various items comprising the preliminary rite are given in the next chapter (ch. 5), again as an answer to the sages' request for further elucidation.

The next two chapters (chs. 6 and 7 ) are of central importance, as they concern the emotional life of theatre, the rasas and the bhävas. In these two chapters, the germs of an Indian aesthetic theory are laid down, in the celebrated 'aphorism on rasa' (rasasūtra), and through the details on the relationship between the various emotions and their theatrical configurations. The rest of the treatise is devoted to the systematic exposition of all the spectacular elements of theatre, starting with bodily acting (ängikäbhinaya) and related matters (chs. 8-13); vocal acting (vācikäbhinaya), including the text and the plot (chs. 14-20); ornamental acting, including character typologies (chs. 23, 24 and 26); harmonious and pictorial acting (chs. 22 and 25); and the theatrical success (ch. 27), before ending in a long section devoted to vocal and instrumental music (chs. 28-34) and a chapter on role division (ch. 35).

Bharata's narrative about the origin of theatre is brought to a close with the last two chapters (chs. 36 and 37), through the account of the descent to earth of the knowledge and practice of theatre among mortals. This 'descent' occurs as the result of a curse put upon the actors, who misused their histrionic powers to mock the Rșis. The restoration of dramatic art on earth is attributed to a rightful king, Nahuṣa, who requests that theatre be performed in his royal court. By again teaching and performing the art form according to the rules, the curse is removed, and the sons of Bharata can finally return

$5^{8}$ The 'preliminary rite' ( pürvarainga) consists of a series of scenic operations, including instrumental music and songs, and the recitation of a benedictory verse (nāndī), as well as a number of codified gestures executed by the theatre director along with two assistants. The pürvaranga ends with an 'invitation' ( prarocana $\bar{a}$ ) to watch the play, introducing its topic. On the elaborate procedure of the pürvaranga, see Bansat-Boudon 1992: 72-80 and Tieken 20o1. On the significance and origin of the pürvaranga, see especially Kuiper 1979 and Lidova 1994. 
to heaven, leaving the legacy of the Nātyaśästra behind in the form of worldly art, together with their progeny. ${ }^{59}$

This multilayered narrative device situates the creation of dramatic art and the composition of the Nātyaśāstra in a remote past and establishes a tradition of hearers and reciters, starting from Brahmā and Bharata and continuing all the way back to the Rịis (and the present reader, one is tempted to add), who fictionally provide the occasion for the exposition of the text in its present form. The two accounts of the origin of theatre and the introduction of dance into the pürvarainga are on the same narrative level, that of the embedded story or intra-diegetic plot, although they are temporally sequenced. The embedded narrative in fact proceeds in three steps. The first step coincides with the most remote event, the creation of the Nātyaveda by Brahmā and its transmission to Bharata and his sons. The second step takes place once the theatrical arts, with their principal constituents already established (including the theatrical building, the consecratory rites, and the pürvaranga), are put into practice in front of Siva, which leads to the introduction of dance in the pürvaranga, through the intermediary of Tandu. Endowed with the new object, the knowledge of theatre is presumably transmitted anew complete with the instruction on dance, which forms part and parcel of the subject of the śästra in its present form. The third and last step in the narrative concerns the descent of theatre to earth, through the circumstances that led to a new legitimization of the dramatic tradition, before Bharata's sons are finally readmitted to heaven. Thereafter, the chain continues uninterrupted on earth, with Bharata's sons passing on dramatic art to the Apsarases, and his nephews doing the same for successive generations of human teachers and performers. ${ }^{60}$ To ensure the continuity and the authoritativeness of the art, the text of the Nátyaśāstra is left behind on earth: only when theatre is performed according to the rules, the text repeatedly stresses, does it lead to the desired reward.

At some later point in time, contemporaneous with Bharata as the narrator of the intra-diegetic plot or embedded story, the sages approach him in order to be instructed in their turn, and eventually appear throughout the treatise to ask for elucidation on various points and to move the narration forward. These events presumably take place in heaven, where Bharata and his sons returned once the curse was extinguished. At the far end of this chain of transmission

59 On the foundation myth of the Nātyaśāstra, see Bansat-Boudon 1993. For a detailed analysis of the multiple interpretative levels of the curse-and-atonement episode and its logic internal to the Nātyaśāstra, see Ganser \& Cuneo 2012.

6o On the role of the Apsarases in the passage of theatre from heaven to earth, see Ganser \& Cuneo 2012. 
comes arguably the last hearer, the extra-diegetic reader of the present treatise. The text ends its own textual history on a truly tempting note, with the following phalaśruti: 'Whoever listens uninterruptedly to this [Nātyaśāstra], as it has been uttered by the Self-born (Brahmā), or whoever learns it and makes a performance in accordance with its teaching, he will obtain the goal of the experts in the Veda, the goal of the performers of sacrifices, the goal of the bestowers of gifts. ${ }^{\prime} 1$

Now that the narrative structure of the Nātyaśāstra has been sketched in outline, the fourth chapter's place in it, and the instruction on dance it contains, will be taken up next.

\subsubsection{The Tāṇ̣avādhyāya}

The fourth chapter of the Nätyaśästra is commonly known under the name Tândavalakșana ('An Illustration/The Rules of the Tändava'), which is the name given in the colophon of this chapter in Bharata's text. ${ }^{62}$ In the Abhinavabhāratī, it is referred to as Tändavavidhānādhyāya ('Chapter on the Regulation of the Tandava') at the end of the fourth chapter and, in other passages, as Tāndavādhyāya ('Chapter on Tāṇdava') or, less technically, as turyādhyāya ('fourth chapter'), on one occasion specified as nrttavișayaturyādhyāya ('fourth chapter on the topic of dance'). In the Nätyaśāstra, the term tāndava refers to the dance taught to Bharata by Tandu, whereas its archetype is the dance of Siva, performed by the god after the destruction of Dakșa's sacrifice. It is also the name of the dance that was introduced into the 'preliminary rite' (pürvarainga) at the instigation of Śiva himself.

The separate and later incorporation of dance into the theatrical lore according to the narrative of origin, as well as its special connection with Śiva, have led some scholars to postulate an independent tradition for dance, possibly of Śaiva derivation. ${ }^{63}$ In the present state of the text, however, it is in no way possible to establish such an independent status for dance, nor is it my aim to say anything new here about the respective origins of dance and theatre or about the historical process by which dance came to be incorporated into dramatic art. The two appear, in the text of the Nătyaśāstra as we know it today,

61 Nś 37.26-27: ya idaṃ șrnuyāan nityam proktam cedam svayambhuvā | kuryāt prayogam yaś caivam athavā 'dhītavān narah || yā gatir vedavidușām yā gatir yajñakārināàm | yā gatir dānaśîlānāṃ tām gatị̣ prāpnuyād dhi saḥ \|

62 Tãndava Lakșana is also the name given to the volume of Naidu et al. 1980, which contains a translation of this chapter.

63 See, for instance, Kane 1971 and Byrski 1974. 
as already indissolubly intermingled. Given the impossibility of going beyond the structure of the present text until further critical studies are attempted, a few words about the place of dance within the 'Treatise on Theatre', together with some interpretative problems connected to it, are all I can venture at this point.

Although the fourth chapter of the Nätyaśästra is specifically devoted to a detailed explanation of dance in both its formal and practical aspects, it is in the first chapter that dance makes its first appearance in a theatrical context, hence even prior to its formal teaching and introduction into the pürvaranga. As famously reported, Brahmā recalled the four canonical Vedas to create the Nätyaveda (Nś 1.16-17). After its creation as a complex object comprised of different parts, theatre was transmitted to humans (Bharata and his hundred sons) and put into practice (NŚ 1.24-25). Upon the conclusion of their training and their mastering of the three manners ( $v r t t i)$-namely, the bhäratī ('vocal'), sāttvatì ('psychophysical'), and ārabhațī ('dynamic')—Brahmā recognizes that something is missing, namely beauty. To remedy this deficiency, he suggests that the kaiśiki vrtti ('gorgeous manner') should be introduced as well, and asks Bharata to name the material adequate for it (Nś 1.41-43). ${ }^{64}$ Although indeed conscious of the importance of the kaisiki, of which he furthermore had direct experience by witnessing Śiva's dance in the past, Bharata requires the presence of women to put it into practice. He thus asks Brahmā to provide the necessary ingredients for its performance, recalling the dance of Siva as the embodiment and prototype of the 'gorgeous manner':

'Oh blessed one, be pleased to provide the material for putting the gorgeous [manner] into practice. Endowed with the angahäras of dance, consisting of rasas, emotions and actions (1.44), the gorgeous manner, in attractive attire, giving rise to the amorous rasa, has been seen by me in the dance of the blessed Nïlakanțha (1.45). Without women, however, men are not able to perform it.' Thus, the majestic, almighty one generated

64 The four 'manners' ( $v r t t i)$ are the topic of Nś ch. 20 . They are the different 'styles' or 'manners' assumed by Viṣnu during his fight with the demons Madhu and Kaițaba-being verbally expressive at certain times, concentrated, gracious, or vehement at others. The kaisiki vrtti derives its name (lit. 'the manner of the hair') from Viṣnu's action of tying up his topknot, using graceful gestures and dance movements, during the fight, due to a momentary recollection of his loving union with Lakșmī, in 'a languid pause in the fury of the fight', as Lyne Bansat-Boudon (1995: 51) gracefully describes it. On the vrttis and their origin, see Raghavan 1993: 242-315; Wright 1963; Bansat-Boudon 1992: 169-180, 1995; and Lidova 2014. 
the Apsarases (celestial nymphs) with his mind (1.46). For the performance, he handed over to me those [Apsarases], skilful in the ornaments of theatre (1.47ab). ${ }^{65}$

The narrative continues with a list of the names of the Apsarases provided for the sake of the kaisiki ( $\mathrm{Ns} 1.47 \mathrm{~cd}-5 \mathrm{Oab}$ ), together with the appropriate musical and vocal accompaniment arranged, respectively, by Svāti and Nārada (NŚ 1.5ocd-52ab). As the definition of the kaisiki - given in connection with the narrative of origin of the vrttis in Nś ch. 20-confirms, dance is only one of its elements. The 'gorgeous manner' also contains songs, beautiful costumes, and all kinds of material suitable to be connected with the theme of love. ${ }^{66}$ Yet the very narrative of its introduction into theatre suggests that dance constitutes its most characteristic feature, since it is the dance of Śiva that provides its prototype and inspiration. This dance is not just a formal model to be mimetically reproduced; on the contrary, it is through the divine Apsarases that it was introduced into theatre via the kaisiki. Similarly, instrumental and vocal music are introduced into it through Svāti and Nārada.

Once theatre is thus replete with the four $v r t t i s$, it is again practised through a rehearsal by Bharata and his troupe, now also containing the Apsarases and the Gandharvas. This last rehearsal, conducted with the musicians and vocalists, eventually led theatre to its seemingly fully fledged form. It is in this very form that the first performance ever was presented to Brahmā and an assembly of gods and demons reunited on the occasion of the festival of Indra's banner. And it was that very first performance that was visited by obstacles,

65 NŚ 1.44-47ab: dīyatāṃ bhagavan dravyaṃ kaiśikyāḥ saṃprayojakam | nrttāñnahārasaṃpannā rasabhāvakriyātmikā || 44 || dṛștā mayā bhagavato nïlakanțhasya nrtyatah | kaiśikī ślakșnnanaipathyā śrnigārarasasambhavā || 45 || aśakyā puruṣaih sā tu prayoktum strījanād ṛte | tato 'ș̣jan mahātejā manasāpsaraso vibhuḥ || 46 || nātyālañkāracaturāḥ prādān mahyam prayogatah $\mid$

66 The definition of the kaiśikì vrtti in Nś 20.53 reads: yā ślakșnanaipathyaviśeșacitrā strīsaṃyutā yā bahunrttagītā | kāmopabhogaprabhavopacārā tāṃ kaisíkīm vṛttim udāharanti || 'They call the gorgeous manner that which, distinguished by a special attractive attire, is connected with women, contains dancing and singing in abundance, and actions arising from the enjoyment of love.' The ABh ad locum, vol. 3, pp. 99-100 comments: ślakṣnah sukumārah ślișyati hrdaya iti kṛtvā. naipathyaviśeșo vastramālyādih tena citrā, bahu vipulạ̣ gītaṃ nṛttam ca yasyām, kāmopabhogo ratị̣ tatạ̣ prabhavo yaḥ sa śrnigāras tadbahula upacāro vyavahāro yasyām sā tathoktā. 'It is distinguished by a special attire consisting of garments and garlands, that is made attractive, i.e. delicate, clinging to the heart. In it, there are many, i.e. abundant, songs and dances. [And] the actions, i.e. the behaviours in it, abound with the amorous [rasa] that arises from the enjoyment of love (kāma), [the stable state of] desire (rati). Such a [manner] is called "the [gorgeous]"'. 
which eventually required the introduction of a scenic rite apt to secure the blessings of the deities and their protective acts towards the actors and the entire performance. This in its turn entailed the building of a playhouse, the installation of the deities in its various sections, and their propitiation. It moreover necessitated Brahmā's pacificatory discourse to the demons, so as to explain to them the true nature of theatre and how they had misrecognized it. 67

The opening verses of the fourth chapter continue the storyline of the embedded narrative of the origin and transmission of dramatic art as told by Bharata to the R̦̣is:

In this way, having worshipped [the stage], I addressed the progenitor (Brahmā): 'Oh mighty one, command quickly, which performance should be performed?' (4.1). Then the blessed lord told me: 'Perform the Amrtamanthana ("The Churning of the Ocean"). This [play] generates valour (utsāhajanana) and pleases the gods (4.2). This Samavakāra, which I have formerly composed as a means to achieve one's duty (dharma), pleasure (kāma), and wealth (artha), is the performance you ought to perform, oh learned one' (4.3). [When the Samavakāra was performed, gods and demons rejoiced together at the spectacle of actions and emotions (4.4). $]^{68}$ After some time, the lotus-born (Brahmā) told me: 'We shall present today the play to the magnanimous one, the three-eyed (Śiva)' (4.5). Then, having come along with the deities to the abode of [the god] marked by the bull, the progenitor paid homage to Siva and said: (4.6) 'Oh best among the gods, be so kind as to do me the favour of listening and watching this Samavakāra, which I have composed' (4.7). Siva replied to Brahmā with the words: 'I shall watch the play.' Then the blessed one told me: 'Get ready, oh magnanimous one' (4.8). Thereafter, on the top of the Himālaya, abounding with numerous mountains full of many Bhūtaganas, with beautiful valleys and waterfalls, (4.9) the preliminary rite (pürvaranga) was first performed, oh best among the twice-borns,

67 On the aesthetic failure of the first theatrical performance, see Bansat-Boudon 2012.

68 This verse parallels Nś 4.11ab (tato bhütagañā hrșțāh karmabhāvānukìrtanāt |) and is not commented upon by Abhinavagupta. If this is an interpolation, which I strongly suspect, Abhinavagupta's comment - that after the teaching was completed, the Amrtamanthana was first shown to Śiva, and not to Brahmā or the other gods (see ABh ad Nś 4.5 below) would be justified. This verse is also absent in many of the Nś manuscripts collated in Tripathi 2015: 55, although it has been retained by Kavi. I have therefore decided to put it here in square brackets. 
and then this (i.e. the Samavakāra). Along with it was also performed the Tripuradāha ('The Burning of the Three Cities'), technically defined as a Dima (4.10). ${ }^{69}$

If we regard the fourth verse in Bharata's text as spurious, the spectacle shown to Śiva constitutes the first-ever performance of a fully fledged play preceded by the pürvarainga. To be sure, there are actually three elements in this performance: the pürvarainga, the Amrtamanthana Samavakāra, and the Tripuradāha Dima. ${ }^{70}$ Enigmatically, the purrvaranga finds its first mention in the whole Nätyaśāstra in this very passage, without any previous indication of instituting the practice of the preliminary rite before a play. In the first chapter, we were told that the first attempt at producing a play was interrupted by obstacles, which required a consecration of the scenic space (rangadaivatapüjana), an event referred to also at the beginning of this chapter (cf. Nś 4.1a evam tu

69 NŚ 4.1-10: evam tu pūjanam krtvā mayā proktah pitāmahah |ājñāpaya vibho kṣipram kạ prayogah prayujyatām || 1|| tato 'smy ukto bhagavatā yojayāmrtamanthanam | etad utsāhajananaṃ suraprītikaraṃ tathā || 2 || yo 'yaṃ samavakāras tu dharmakāmārthasādhakah | mayā prāg grathito vidvan sa prayogah prayujyatām $\|_{3}||$ [tasmin samavakāre tu prayukte devadānavāh | hrșțāh samabhavan sarve karmabhāvānudarśanāt || 4 ||] kasyacit tv atha kālasya mām āhāmbujasaṃbhavaḥ | nātyam sandarśayāmo 'dya trinetrāya mahātmane \| 5 || tataḥ sārdham surair gatvā vrșabhāñkaniveśanam | samabhyarcya śivaṃ paścād uvācedam pitāmahaḥ || 6 || mayā samavakāras tu yo 'yam srșțaḥ surottama | śravaṇe darśane cāsya prasādam kartum arhasi || 7|| paśyāma iti deveśo druhiṇạ̣ vākyam abravīt | tato mām āha bhagavān sajjo bhava mahāmate || 8 || tato himavatah prșțhe nānānagasamākule | bahubhūtagaṇākîrne ramyakandaranirjhare $\|9\|{ }^{*}$ pürvarañge krte $\left[\Sigma_{\mathrm{M}}\right.$ : pürvarañgah krtaḥ $\Sigma_{\mathrm{E}}$ ] pūrvaṃ tatrāyam dvijasattamāḥ| tathā tripuradāhaś ca dimasaṃjñah prayojitạh || 10 || I have changed the text of the editions, pürvarangah krtah pūrvam, into the locative absolute pürvarange krte pürvam, following Abhinavagupta, who quotes this verse as such twice: in ABh ad Nś 5.4, vol. 1, p. 208, with which all manuscripts agree, as well as in ABh ad Nś 1.56, vol. 1, p. 25, with a slight variation but clearly referring to the same verse: tathā caturthe 'dhyāye vakșyate: pūrvarange krte mayā bhagavate śivabhaț̣ārakāya darśita $i t i$. The manuscripts that quote the full verse in ABh ad Nś 4.10a, or have a longer pratīka, unanimously read pürvarange krte.

70 These are two of the ten dramatic genres, described in Nś 18.2-3ab as Nāțaka, Prakarana, An̉ka, Vyāyoga, Bhāṇa, Samavakāra, Vīthī, Prahasana, Ḍima, and Īhāmṛga (nāṭakam sa-

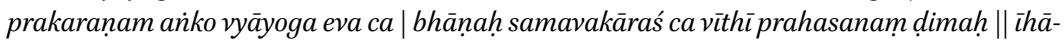
mrgaś ca vijñeyo daśamo nātyalakșaṇe ||). Of the two dramatic genres of Samavakāra and Dima there are almost no specimens. The only available Samavakāra is the Samudramanthana by Vatsarāja (twelfth century CE), who also wrote a Dima called Tripuradāha. A few other specimens of Dima are available, but they are even more recent. The names given by Vatsarāja to these two plays clearly follow those of the Nātyaśāstra, suggesting the artificiality of the plays belonging to these two genres. For more on their plot, see Keith 1924: $267-268$. On the distribution and productivity of the different theatrical genres in the classical and medieval period, see Leclère 2013: 42-46. 
püjanam $k r t v \bar{a})$. This fact has led to a multiplicity of interpretations regarding the separate identities of the rangadaivatapüjana and the pürvaranga. ${ }^{71}$ Following the analysis of the narrative sequence of the Nātyaśästra, it appears that the rangadaivatapujana described in the third chapter is a ceremony of consecration taking place solely on the occasion of the construction of a new theatrical building, and that is how it is recalled at the beginning of the fourth chapter. It is followed closely by the theatrical rehearsal and production of a new play, which eventually requires a pürvaranga prior to its public staging before an audience.

Quite evidently, the context of the second performance differs considerably from that of the first one, which was shown to the gods during the festival of Indra's banner, as described in the first chapter. Here it is not specified which event-be it a religious festival or a commemoration-occasioned the performance shown to Śiva. It is the spectator of this second performance who will prompt the addition of a further element, i.e. dance, to the purvarainga:

Thereafter, the Bhūtaganas all rejoiced at the re-narration of actions and emotions, and the great god, delighted, spoke thus to the progenitor (4.11): 'Oh magnanimous one, you have produced this play well, conferring fame, with an auspicious topic, righteous and improving the intellect' (4.12). But I, who dance at the twilight hour, have recollected this dance, embellished by angahäras replete with various karanas (4.13). May you use it in the proper way in the course of this purvarainga, when the vardhamānaka is performed, as well as in the gitakas and āsāritas. $^{72}$ And in the mahāgitas, you should properly enact the mea-

$71 \quad$ According to Kuiper (1979: 162), the pürvarainga is 'a doubling of the consecration', which was probably never performed in its full form, while Bansat-Boudon (1992: 78-79) maintains, on the basis of Abhinavagupta's commentary, that both the rangadaivatapüjana and the purvaranga were performed consecutively at the beginning of each theatrical performance. The importance of the pürvaranga, she remarks, lies in its anticipation of some of the elements of the following play, which pleads for its necessarily being performed before it. Lidova (1994), on the contrary, refrains from using the Abhinavabhäratī, and proceeds to analyse a number of textual sources that describe the püja outside a theatrical context, but bear strong resemblance to the phases of the rangadaivatapüjana as described in the Nātyaśāstra. Moreover, she finds a parallelism between the operations executed in the rangadaivatapüjana described in Nś ch. 3 and those performed in the pürvaranga, and concludes that the latter constitutes a later development of the former, which came to substitute the older püjā rites. Scholarly opinions on the actual performance of the pürvaranga in the classical period also differ (cf. Tieken 2001).

72 On the complexities of these types of musical compositions to be performed in the preliminary rite, see, for instance, Te Nijenhuis 1970 and Ramanathan 1999. 
nings ${ }^{73}$ (4.14-15ab). This pürvaranga that you have performed as plain (śuddha), once commingled with these [ägahäras], will be known as 'variegated' (citra) (4.15cd-16ab). Having listened, the self-born replied to the words of the great god: ${ }^{74}$ 'Oh best among the gods, do teach the performance of the angahäras' (4.16cd-17ab). Then, the lord of the universe (Śiva) called Tandu and said: 'Do instruct Bharata in the performance of the angahäras' (4.17cd-18ab). ${ }^{75}$

After Śiva's prompting Tanḍu to teach the angahäras to Bharata, the text typically shifts back to the dialogue frame, where Bharata, before proceeding to the exposition of the various dance movements, addresses the R̦sis directly:

Therefore, I will now explain to you the angahäras, connected to the karanas along with the recakas, as Tāndu, the great soul, illustrated them $(4.18 \mathrm{~cd}-19 \mathrm{ab}) .{ }^{76}$

The second introduction of dance into theatre as an independent element and not as part of the kaisiki vrtti occurs at this very juncture. It is clearly as a result of the delight produced in Siva by the performance that the god is prompted to grant dance, endowed with a formalized technique, as a token of his appreciation.

On the one hand, the reason for introducing dance into drama is of an aesthetic nature: Bharata had seen the dance of Śiva - as we were told in the first chapter - and added it to the performance, together with the other elements of the kaisiki vrtti (women performers, songs, instrumental music, etc.), so as

73 On the thorny interpretation of this hemistich, where abhinaya is mentioned in connection to dance, see $\S 2.4, n$. 129, and Translation 7.2.2.

74 I read maheśvaravacaḥ praty uktạ̣ (given as variant reading in the Kāvyamālā edition of 1894), instead of pratyuktas, following the reading of the commentary.

75 NŚ 4.11-17cd: tato bhütagaṇā hrșțāḥ karmabhāvānukīrtanāt | mahādevaś ca suprītah pitāamaham athābravīt || 11 || aho nāțam idam samyak tvayā șrștam mahāmate | yaśasyam ca subhärtham ca punyam buddhivivardhanam || 12 || mayā 'pìdam smṛtam nịttaṃ sandhyākāleșu nrtyatā | nānākaraṇasaṃyuktair añgahārair vibhūṣitam || 13 || pūrvarañgavidhāv asmiṃs tvayā samyak prayojyatām | vardhamānakayogeșu gīteșv āsāriteșu ca || 14 || mahāgīteșu caivārthān samyag evābhineșyasi | yaś cāyam pūrvaraingas tu tvayā śuddhaḥ prayojitah || 15|| ebhirvimiśritaś cāyam citro nāma bhavisyati| śrutvā maheśvaravacah praty uktạ̣ [Kāvyamālā Ed. 1894, pratyuktas $\mathrm{E}_{1}$ ] tu svayaṃbhuvā || $16 \|$ prayogam à̃gahārāṇām ācakșva surasattama | tatas tậ̣̣um samāhüya proktavān bhuvaneśvarah || 17 || prayogam añgahārānām ācakṣva bharatāya vai |

76 NŚ 4.18cd-19ab: tato ye tậ̣unā proktās tv añgahārā mahātmanā || tān vah karaṇasamyuktān vyākhyāsyāmi sarecakān | 
to add beauty. Unlike theatre, dance is not an object created anew to respond to some circumstantial need, such as the degradation of society and the ritual sphere, and the consequent need to extend the teachings on the aims of mankind to all fringes of the population. On the other hand, the absence of a formal teaching coming along with the gift of theatre personnel-the Apsarases-in the first chapter, requires a further transmission of dance in order to perfect it. ${ }^{77}$ Although Siva is the archetypal performer of dance, it will be the task of Tanḍu to instruct Bharata in this art form.

The content of Tandu's instruction follows this narrative interlude as an exposition of the main dance components: the karanas (basic combinations of movements) and the angahäras (choreographic sequences made of karanas). This exposition comprises their enumeration (uddeśa) and definitions (lakșana), which occupy a large section of the fourth chapter (vv. 19cd-247), and consist of a set of highly technical instructions, unique in the genre. These verses were probably intended as mnemonic aids, since it is impossible to understand how specific karanas, and the angahäras derived from them, are formed without previous knowledge of the single definitions of their components (gestures, limb movements, bodily postures, etc.). Even then, reconstructing the karanas as a single connected movement is an arduous if not impossible task. ${ }^{78}$

The example of first karana, called talapuspaputa ('handful of flowers'), may suffice to illustrate the commonality of the building blocks shared by both dance and dramatic acting:

vāme pușpapuțaḥ pārśve pādo 'gratalasañcarah $\|$ tathā ca sannatam pārśvam talapuspapuțam bhavet | (4.61cd-62ab)

Talapușpapuța: [The hand] pușpapuța is [held] on the left side, the foot is agratalasañcara, and the side is nata ('bent').

The definitions of the three specific bodily movements involved in this karana have to be supplied from the later chapters on the bodily acting (āingikäbhinaya), where they are in turn presented in the same concise form. ${ }^{79}$ The strong dependence of the definitions of the dance movements in the fourth chapter on the later sections about dramatic acting was noticed and pointed out by Naidu et al.:

77 This is how Abhinavagupta explains it, on which see below, $§ 2.4$, n. 118.

78 On the various attempts at reconstructing karana techniques from the texts in the twentieth century, see $\S 1.2$.

79 The pușpapuța hand gesture is defined in Nś 9.15o, the agratalasañcara foot in Nś 9.273cd274ab, and the nata side position in Nś 9.235 . 
It is true that Bharata has followed an apparently unnatural order in discussing the great topic of Abhinaya. The Karanas are defined in the fourth chapter, while the technical terms used so profusely in the definitions are explained only in the eighth, ninth, tenth and eleventh chapters. The most surprising fact is that these explanations are couched in such simple language that, if the learned author had only rearranged the chapters so that the fourth chapter came after the eleventh, then, even the uninitiated would have no difficulty in following the exposition.

NAIDU et al. 1980: 13

The problem of the chapter arrangement in the economy of the text can be solved by resorting to the perspective of the intra-diegetic narrator as a character in the origin story: Bharata in fact reports the definitions of the karanas, as Tandu had illustrated them to him at a time when he and his troupe had already assimilated all the knowledge of dramatic art, so their knowledge of the technical terms pertaining to the teachings on āngikäbhinaya can be presupposed..$^{80}$ Obviously enough, the chosen arrangement reduces the pedagogical value of the Nātyaśāstra as a practical manual of instruction, while it makes perfect sense if one thinks of it in terms of the narrative it expounds.

Having provided the complete catalogue of dance movements, Bharata again intervenes in the guise of the intra-diegetic narrator and dialogue partner of the R̦sis, with four verses that explain the origin of another group of dance movements or configurations. Of the units characterizing this group, called pindibandhas, the definitions are laid down in vv. $253 \mathrm{~cd}-259 \mathrm{ab}$, without them being announced either in the narrative of the origins of theatre or in the narrative of the introduction of dance into the purvaranga, which is its continuation. The four verses introducing the pindībandhas are quite at odds with the rest of the narrative: the commentator sets these verses off as purākalpa, a story of primordial events connected to the Dakșa myth and the role of Siva's dance in it.

Having seen Śaṅkara dancing with recakas and angahāras and Pārvatī dancing in the delicate manner (sukumāraprayoga) (4.249cd-25oab)— Maheśvara, who, [accompanied] by the sound of all [kinds of] percussion (ātodya), such as mrrdanga, bherī, pațaha, bhānda, ${ }^{81}$ dinḍima, gomukha,

8o This is also how Abhinavagupta responds to an objection similar to the one expressed above by Naidu et al. (1980: 13), in ABh ad Nś 4.29cd-3oab, vol. 1, p. 91.

81 In ABh ad Nś 1.85, bhända is explained as a term encompassing the three main drums, namely the mrdariga, the panava, and the dardura, along with their implements, probably 
panavas, and darduras (4.250cd-251ab), following the destruction of Dakșa's sacrifice, started to dance in the twilight hour, with various angahäras governed by tempo and rhythm (4.251cd-252ab) - the Ganas, headed by Nandin and Bhadra, saw the pindibandhas in those [dance movements], gave names to the pindis and made bandhas of them, together with [their] definitions $\left(4.25^{2 c d}-253 \mathrm{ab}\right) .{ }^{82}$

The myth about the destruction of Dakșa's sacrifice is well attested in the early sources, and has several versions, differing from one another, in the Mahābhärata and other Purānas. ${ }^{83}$ In the version of the myth staged in Nś 4.249cd-253ab, we are not told whether the dance following the destruction of Dakșa's sacrifice is also a destructive dance, or rather one of jubilation. In the first verse, Śiva is even said to be dancing together with Pārvatī, who adopts the delicate mode of performance (sukumära prayoga). The presence of a delicate dance after such a fierce event made some scholars, such as K.M. Varma (1975: 35), consider the first verse mentioning Pārvatî's gracious dance as incoherent with respect to the mythological narrative, and even spurious. Varma thus suggests that the mention of the delicate style in Nś $4.25 \mathrm{Oab}$, as well as its later occurrences in vv. 4.269ab, 4.302cd, and 4.303, must have been added to the text at a time when the opposition between tạndava and lāsya (a synonym for sukumāraprayoga, according to Varma) needed to be legitimized by tracing it back to the text of the Nātyaśāstra.

It might be pointed out that, according to the latest edition of the Nätyaśästra by K.D. Tripathi, v. $249 \mathrm{~cd}-25 \mathrm{oab}$ (4.242cd-243ab, in Tripathi) is found neither in the two newly collated manuscripts from Jaipur (called $\mathrm{J}_{1}$ and $\mathrm{J}_{2}$ ), nor in the two manuscripts used in the Kāvyamālā edition of 1984 (Kāv. A, in Tri-

the smaller drums such as jhallarī, pațaha, etc. (bhäṇ̂a iti tripuṣkare sopakaraṇe, vol. 1, p. 31). I strongly doubt that the reading bhānda is correct here, since we would rather have a single instrument in this position. One possible candidate is jañjhā, found together with bherī and pațaha in Nś 34.26. This resembles the form jhañjhyā read in $\mathrm{E}_{1(2)}{ }^{\text {Da }}$. The text of Nś 34.26 itself, however, looks corrupt, with manuscripts offering the following variants:

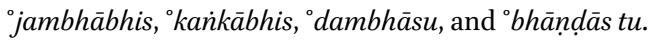

82 Nś 4.249cd-253ab: recakair añgahāraiś ca nrtyantam vīksya śañkaram || 249 || sukumāraprayogena a rrtyantīm caiva pārvatīm | mrrdañgabherīpațahair bhāṇdadịndimagomukhaih || 250|| panavair darduraiś caiva sarvātodyaih pravāditaih | dakșayajñe vinihate sandhyākāle maheśvaraḥ || 251 || nānāngahāraih prānrtyal layatālavaśānugaị | pị̣̂̄ībandhāṃs tato drșțvā nandibhadramukhā gaṇāh || 252 || cakrus te nāma piṇ̣̂inām bandham āsāṃ salakșaṇam |

83 On the myth of Dakșa and its numerous versions, which do not usually contain references to dance, see Mertens 1998, Kramrisch 1981: 322-330 and Klostermeier 1984: 136-145, and, for more recent information, Skandapurāna vol II B, p. $6 \mathrm{ff}$., and Bakker 2014: 173-187. 
pathi). All the other manuscripts, among which are the oldest witnesses from Nepal (dated from the 13th c. onwards), mention the sukumäraprayoga in this verse. What we also know with certainty is that Abhinavagupta knew this verse and recognized it as part of the original composition. Yet he takes particular notice of the rather convoluted syntax of this quartet of verses, the difficulties arising from their order as well as their content that links the Daksa motive, Śiva's dance, and the delicate style assumed by Pārvatī ${ }^{84}$ We can thus conclude that, in the version circulating in Kashmir at the beginning of the second millennium, this is how the myth was rendered, with the divine couple dancing together after the destruction of Dakșa's sacrifice, and Śiva's attendants also dancing along.

Unlike the karanas and angahäras, the pindībandhas are not defined in terms of body movement, so it is not clear precisely how these shapes or figures looked, nor is there a way to verify how they were used in ancient theatre. In the secondary literature on dance, they are generally understood as group dances performed in the pürvarainga by a formation of female dancers. ${ }^{85}$ The Nätyaśāstra limits itself to listing the names of the pinḍ̄is in association with the various deities to which they are linked (vv. 253cd-259ab). The mythological account of the dance performance following the destruction of Dakșa's sacrifice is brought to a close by mentioning how the complete set of dance movements - the recakas, the angahäras, and the pindībandhas-was transmitted from Śiva to Taṇu u, and how Taṇ̣u connected dance with instrumental and vocal music, giving rise to the tândava (vv. 259cd-261ab). ${ }^{86}$

This is followed by the R̦̣is' questions about the nature and place of dance in the dramatic performance and in connection with the songs of the pürvaranga. ${ }^{87}$ In the account of the introduction of dance in the preliminary ritual related in the Tândavādhyāya, Siva had in fact suggested using dance in the gitakas, àsāritas, and vardhamāna. The final portion of the fourth chapter (Nś 4.269cd-318) lays down the technical instructions about the use of dance in connection with the various segments of songs with which it is associated in the pürvaranga. These instructions presuppose a thorough knowledge of

84 For more on the question of tāṇ navagupta, see $\S 2.3$.

85 See, e.g., Bose 2007: 112-116. For a new interpretation of the pindìbandhas as connected with the religious-ritual function of dance, see Ganser (forthcoming).

86 On the connection of dance with music and its consequences in the development of new dance genres, see $\S 2.4$ below, and for Abhinavagupta's interpretation of these verses, crucial in his interpretation of creativity within the tradition, see $\S 2.5$.

87 This portion of the text and its commentary, corresponding to Nś 4.261cd-269ab, have been critically edited and translated in Part 2 of the present book. 
the procedure of the various phases of the preliminary rite, which are elaborated in the fifth chapter, as well as of the musical tradition described later in the music chapters (chs. 28-34). Again, this dependence of the fourth chapter on the fifth compelled Varma (1957: 35-37) to argue that the whole section, starting from the second mention of the sukumäraprayoga side by side with the vehement dance (uddhata) and up to the end of chapter 4 (vv. 268cd320 ), must be spurious and result from interpolation, since these verses are devoted to the illustration of dance as used in the preliminary rite, a subject he regards as logically belonging to the fifth chapter. Again, the perspective of the outermost narrative frame, formed by the dialogue between Bharata and the Rșis, can tentatively explain why a detailed exposition of the pürvarainga should come as an appendix to the chapter on dance. The fifth chapter is in fact occasioned by the questions of the sages who, having heard that a pürvarainga was performed before the play was shown to Śiva, asked about its details.

First introduced into the body of drama as an element of the kaisiki vrtti, dance further made its way into the pürvaranga, for the sake of making it 'variegated' (citra). The very first mention of the pürvaranga, however, occurs abruptly and without previous notice in the fourth chapter, where the performance is simply said to be preceded by a 'plain' pürvarainga (Nś 4.10), which must be connected to the worship of the stage instituted in the first chapter in order to secure the blessings of the deities and thereby their protection. In consequence, the history of the origin of theatre looks like a history of successive additions and expansions of a still incomplete object, justified each time by a mythical antecedent going back to the time of the gods. Such moving back and forth between different timelines and narrative frameworks, combined with the potential open-endedness of the object of śāstra, makes the structure of Bharata's Nātyaśästra particularly hard to follow. This explains a certain tendency, among scholars, to consider everything that does not perfectly fit into the main structure of the text as an interpolation. In the present state of the text, it is not possible to solve all the difficulties outlined above, which are especially relevant for evaluating the role of dance in the theatre described by Bharata and its historical development. I have therefore chosen not to discuss the original composition of the Nătyaśāstra and the authenticity of the text as we have it now, but to concentrate on Abhinavagupta's understanding of the version of the text he had in front of him in the early eleventh century in Kashmir. Utmost attention is therefore paid to his exegetical strategies and their contextual aim, without expressing value judgements about the historical accuracy and soundness of his interpretations. After all, commentaries are not simply paraphrases, but true creative acts. 


\subsection{The Abhinavabhāratī: A Medieval Document on Performance}

Some five to ten centuries later than the supposed date of the Nātyaśāstra, Abhinavagupta composed a commentary on it, the Abhinavabhāratī, also called Nātyavedavivrti or Nātyaśāstravyākhyā in some of the chapter colophons. Unlike with many other Indian authors, details about Abhinavagupta's life and works are plentiful. To the pieces of information he himself recorded in his writings can be added those transmitted by his epigones. ${ }^{88}$ Some of his works report the date of composition, by means of which we can quite safely situate Abhinavagupta's activity between ca. 950 and 1025 CE (the last dated work is from $1015 \mathrm{CE}$ ). The centre of his activity was Kashmir, though his fame spread far beyond the boundaries of his home country, as he became one of the most celebrated mystics, poeticians, and philosophers of his time.

Abhinavagupta's multifaceted production comprises a bulk of texts devoted to tantric speculation-among which his original work Tantrāloka stands out - a few but influential commentaries of poetical and dramaturgical content, and a set of philosophical works that culminate in the two famous commentaries on the Íśvarapratyabhijñākārikā and its lost Vivrti authored by Utpaladeva (fl. 925-975), Abhinava's paramaguru in the Pratyabhijñā system. Despite the uncertainty of the relative chronology of Abhinavagupta's works, connected with the plausible hypothesis that he worked on more than one text simultaneously, ${ }^{89}$ it is generally agreed that his two major works on poetics and dramatics, the Dhvanyālokalocana and the Abhinavabhāratī, were composed one after the other and in that sequence. ${ }^{90}$ These two commentaries arguably follow the Tantrāloka, ${ }^{91}$ and they appear to predate the Iśvarapratyabhijñāvi-

88 On Abhinavagupta's life, see the final stanzas of Tantrāloka 37 and those of the Parātrimsíkāvivarana. There is also a pen portrait of Abhinavagupta, possibly teaching the Abhinavabhāratī, by his disciple Madhurāja, on which see Pandey 1963: 3-26.

89 According to Pandey, Abhinavagupta started to work on the Bhagavadgitārthasamgra$h a$ - a commentary on the Gita from a monistic Śaiva perspective-while he was writing the Abhinavabhäratī. This view appears to be based on the sole evidence of a note on the word anyatra in a manuscript of ABh ad Nś 6, section on śāntarasa, vol. 1, p. 337, which reads: anyatra bhagavadgītāryākhyāyām (Pandey 1963: 33-34).

90 Besides the greater sophistication of Abhinavagupta's aesthetic theory in his commentary on Bharata's Nātyaśāstra, the chronological priority of the Dhvanyālokalocana is confirmed by Abhinavagupta's references, in the Abhinavabhäratī, to theoretical developments already expounded in his commentary on Ānandavardhana's work, to which he refers three times: twice under the name Sahrrdayālokalocana (ABh ad Nś 7.1, vol. 1, p. 337 and ABh ad Nś 16.5, vol. 2, p. 30o), and simply as Vivarana in the third instance (ABh ad Nś 19.76a, vol. 3, p. 42). On the chronology of Abhinavagupta's works on literary criticism, see Ingalls et al. 1990: 31 .

91 Pandey argued that the Dhvanyālokalocana mentions the Tantrāloka. However, as noted 


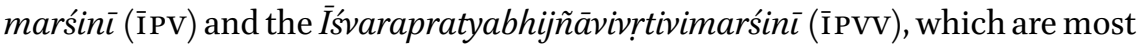
probably his last extant works and represent the summit of his philosophical views grounded in Somānanda's and Utpaladeva's Pratyabhijñā school. ${ }^{92}$

The classical division of Abhinavagupta's works into three main areas of production, although useful for expository ends, fails to account for the multiple influences that many of Abhinavagupta's texts display. ${ }^{93}$ It is usually assumed that the chapters on rasa and bhāva in the Abhinavabhäratī, in which Abhinavagupta's aesthetic theory is laid down, have a highly philosophical character and cannot be understood unless one keeps in mind their philosophical basis. ${ }^{94}$ However, given the fact that Utpaladeva already used aesthetic terms and concepts to make philosophical arguments, it remains unclear whether these were borrowed by the Pratyabhijñā philosophy via dramatic speculation,

by Ingalls et al. 1990: 32 , n. 27 , this is the result of a corrupt reading of the title of a lost work called Tattvāloka, attributed to Ānandavardhana.

92 The İ́varapratyabhijñãvivrtivimarśin̄i is dated 1050 (Sanderson 2007: 412), but the chronological order of the ĪPVV and the ĪPV is uncertain, and what Bhāskara says in his subcommentary, although showing a propensity for the priority of the $\overline{\mathrm{I}} \mathrm{PVV}$, is contradictory. A passage in the İPVV makes reference to the Vimarśinī, which has led R. Torella to opt

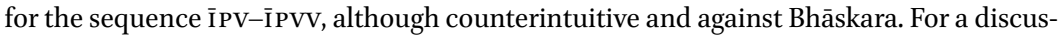
sion of the chronology, see Torella 2002: xliii. As to the Abhinavabhäratī, the İPvv knows it and quotes it three times: vol. 2, pp. 178-179: ayam artho 'bhinavabhāratyām nātyavedavivrtau vitatya vyutpādito 'smäbhir iti. Curiously enough, the other two references to the ABh quote two stanzas preceded by the mention yathoktam abhinavabhāratyām (vol. 2, p. 48) and yad abhinavabhäratī (vol. 3, p. 138). These, however, are not found in the extant version of the text, so they possibly belong to the lost part of the commentary on the seventh or eighth chapters, although verses are in general much less frequent than prose passages in the Abhinavabhäratī. The Abhinavabhāratī, in turn, appears to know a commentary on Utpaladeva's İsvarapratyabhijñākārikā (ĪPK), since it mentions Abhinavagupta's own Vivarana on his paramaguru's work in ABh ad Nś 14.3, vol. 2, p. 224: [...] iti vibhaktam asmatparamagurupādaih pratyabhijñādau, asmābhiś ca tadvivaraṇe bhedavādavidārānāädau ca. The Bhedavādavidāraṇa is a lost work of Abhinavagupta mentioned also in the İPV and in the Gitārthasamgraha (Ratié 2011: 328-329). If the Vivarana is the $\bar{I} \mathrm{PV}$, then we should have the sequence $\overline{\mathrm{I}} \mathrm{PV}-\mathrm{ABh}-\overline{\mathrm{I}} \mathrm{PVV}$, but if it is the $\overline{\mathrm{I}} \mathrm{PVV}$, we have to suppose that Abhinavagupta was working on it at the same time as the $\mathrm{ABh}$, or that different versions of one of the two texts existed, possibly due to a subsequent reworking.

93 The most complete and wide-ranging study on Abhinavagupta remains the homonymous work by Pandey (1963). In it, the tripartite division into broad areas of theoretical speculation was first presented as a chronologically ordered one, in which Abhinavagupta's works are assigned to a tāntrika, an ālaṃkārika, and a philosophical phase (ibid.: 27-34). Ingalls et al. 1990: 32 and Gnoli 1999: 1xxvi have questioned, with good reason, the soundness of the threefold scheme devised by Pandey.

94 This is especially the case with śänta, the 'pacified' rasa, on whose philosophical connotations, see Raghavan 1940; Pandey 1963; Masson \& Patwardhan 1969, 1970; Gerow \& Aklujkar 1972; and Gerow 1994. 
or whether aesthetic concepts were developed in the former independently as part of religious-philosophical speculation, and then found their way back into aesthetic theory via Abhinavagupta. ${ }^{95}$ What is sure is that many of the concepts developed in his poetic and dramaturgical works find a prominent place in tantric and philosophical speculation as well. ${ }^{96}$

Abhinavagupta's curriculum typically includes a great variety of subjects, and the names of his teachers in the different disciplines are known from his own works. ${ }^{97}$ Despite this, a complete picture of the number of sources and authors that influenced him and contributed to shaping his views on a vast array of topics has not yet been satisfactorily drawn. Not only did a range of different tantric schools of Śaiva orientation prosper between the eighth and eleventh centuries in Kashmir, ${ }^{98}$ but a number of philosophical schools of Brahmanical and Buddhist affiliation engaged in rational debate. ${ }^{99} \mathrm{~A}$ period of

95 One instance in point is the concept of camatkāra ('inner deep savouring', Torella forthcoming) developed by Utpaladeva in the İPK and Vrtti and then introduced by Abhinavagupta as a main aesthetic concept. On camatkāra in Utpaladeva's Pratyabhijñā, see Gnoli 1968: xlv-xlvi; Torella 2002: 118, n. 23; and Ratié 2011: 505-507. See also Cuneo 2016a: 34-35, n. 7 for references to camatkāra or camatkrti in other works by Utpaladeva. Another case could be carvana ă, also a prominent term in Utpaladeva's philosophy. On the philosophical matrix of Abhinavagupta's aesthetics, see, e.g., Masson \& Patwardhan 1969 and Pandey 1963. For the opposite view, which looks at Abhinavagupta's metaphysics in the light of his aesthetics, see Gerow 1994. For a summary of the different positions on the direction of philosophical and aesthetic influence in Abhinavagupta's work, and for a nuanced interpretation of the development of an aesthetic sphere within philosophy, see Cuneo 2016a, in particular pp. 38-40. A new interpretation has been recently proposed by Torella who, looking at Abhinavagupta's aristocratic background as a Rājānaka ('Sir'), affirms: 'I am more and more inclined to give prominence to a basic aesthetic flavour as the more or less hidden background of his activity as a whole. This aesthetic flavour goes hand in hand with an aristocratic attitude, the latter being allegedly the very source where the former stems from' (Torella 2020: 845).

96 I need not repeat here the non-dualistic Śaiva philosophy developed by Abhinavagupta, since the chapter of the Abhinavabhāratī forming the subject of this book is less directly influenced by it. Yet it will be shown on the appropriate occasions how some of the philosophical tenets of the Pratyabhijñā are nevertheless presupposed or implicit in statements about dance. On the connections between the aesthetic and religious spheres in Abhinavagupta's work, see Gerow 1994; Bäumer 2003; Ratié 2011; Törzsök 2016; and Torella (forthcoming).

97 Especially, but not exclusively, Tanträloka 37; cf. Pandey 1963: 11-13, Gnoli 1999: lxxv.

98 Among which the Kula, the Krama, the Trika, and the Spanda school. See, e.g., Sanderson 2007.

99 In this respect, and on the bold entrance of the Pratyabhijñā into the philosophical arena with Utpaladeva, see Torella 2002 and Ratié 2011 . On a variety of intellectual debates taking place in different fields in Kashmir around the turn of the millennium, see Franco \& Ratié 2016. 
cultural flourishing encompassing almost every field of knowledge is known to have taken place in Kashmir under the great kings Jayāpị̣a (r. c. 773/4804/5 CE), Ajitapịạa (r. c. 813/4-85o/1 CE), Avantivarman (r. 855/56-883 CE), and Śankkaravarman (883-902 CE). ${ }^{100}$ Under the reign of these kings, the artistic tradition also found new vigour, and was at the same time provided with a new theoretical basis, expressed through works of systematization and a sustained commentarial activity. ${ }^{101}$

Abhinavagupta composed two major works on poetics and dramatics, the Dhvanyālokalocana and the Abhinavabhäratī. In the Locana, he sealed the association of the concepts of dhvani, the 'poetic resonance' theorized by Ānandavardhana (late 9 th c.) as the essence of poetry (kāryasya $\bar{a} t m \bar{a})$, and rasa, the flavour or essence of a play or a literary work. In the Abhinavabhāratī, an extremely erudite and difficult prose commentary on the Nātyaśāstra, he developed his aesthetic views, known as the 'theory of rasa', especially focusing on the dramatic field. He also wrote, in the field of literary criticism, the Ghatakarparakulakavivrti, a commentary on the short poem Ghatakarpara ('Fragments of a Pot') attributed to Kālidāsa, ${ }^{102}$ and the now-lost Käryakautukavivarana, which comments on the likewise lost Käryakautuka ('Wonder of Poetry'), a work on poetics by Bhatța Tauta. ${ }^{103}$ As Abhinavagupta reminds his

100 Dates given in Sanderson 2009.

101 On the presence of intellectuals in these courts, see Smith 1985 and Ingalls et al. 1990. Udbhața, Dāmodaragupta, and Vāmana famously worked at the court of King Jayāpị̣a who, according to the tradition recorded in the Rajjatarangini, was very fond of theatre, and even brought a temple dancer to Kashmir to make her his queen (Raghavan 1980: 101102). Udbhața wrote a commentary on the Kāryālaṃkāra of Bhāmaha (whose fragments have been published by Gnoli 1962); the extant Kāryālaṃkārasārasūtra, commented upon in Pratīhārendurāja's Laghuvrtti; as well as a lost commentary on the Nātyaśāstra, some quotations of which survive in the Abhinavabhäratī. On Udbhața, see especially Bronner 2016. Dāmodaragupta is the author of the sui generis poem Kutțanimata, an invaluable source of information about the actual staging of Sanskrit plays in medieval India. See Dezső \& Goodall 2012. Vāmana is the celebrated author of the Kāryālaṃkārasūtra and Vrtti. His work is important in the history of drama since he is the first author to blur the distinction between dramatic and poetic genres, drawing both from plays and non-dramatic poetry in his work on literary criticism. This method was adopted by later ălamkārikas, paving the way for the merging of theatre and poetry into a unified theory of the literary text, on which see McCrea 2008: 50-51. During the reign of Ajitapịa lived Śaṅkuka, who commented on the Nātyaśāstra around $850 \mathrm{CE}$, on which see Pollock 2016: 77. Ānandavardhana was active at the court of King Avantivarman, under whose patronage he composed the celebrated Dhvanyāloka ('Light on Poetic Resonance'). On Ānandavardhana, see, e.g., Ingalls et al. 199o and McCrea 2008.

102 For a translation thereof, see Parlier 1975.

103 Some fragments of this work are quoted in the ABh and in the DhĀL. For a collection of 
reader in the Abhinavabhäratī through constant references to him as 'my own teacher' (asmadācārya or asmadupādhyāya), Bhațta Tauta (also spelled Tota) taught him dramatics. In the Dhvanyāloka, on the contrary, his instructor was Bhațtendurāja. ${ }^{104}$

Sanskrit theatre was a popular form of spectacle in eleventh-century Kashmir, as testified by the number of plays and authors quoted in the Dhvanyalokalocana and in the Abhinavabhäratī. ${ }^{105}$ From this wide range of quotations, a lively context of performance emerges, with the staging of plays composed by the great playwrights Kālidāsa, Bhavabhūti, Harșa, and others, all belonging to the classical period of Sanskrit drama. Directions and details on their actual performance as well as details about the composition of theatrical troupes are scattered throughout the Abhinavabhāratī. Side by side with the stage production of Sanskrit plays, other genres of performance start to be recorded in the scholarly tradition. These are mostly expressed in the vernaculars and make profuse use of dance and songs. ${ }^{106}$

Despite the fact that the performing arts underwent substantial development during the many centuries that followed their first textual codification, the Nātyaśāstra continued to represent an almost unquestioned authority in matters of theatre and its allied arts, in particular music and dance. In Kashmir, Bharata's treatise was studied and commented on at least as early as the eighth century CE. A number of commentaries preceding that of Abhinavagupta are in fact known through quotations in the Abhinavabhāratī. ${ }^{107}$ The reason for their

Bhațta Tauta's quotations, see Raghavan 1980:108-121 and Pollock 2016:181-187. According to Raghavan, Abhinavagupta's first work on poetics is the commentary on Bhațta Tauta's work, since it is quoted in the Dhvanyālokalocana.

104 Bhațta Tauta's and Bhațtendurāja's names are mentioned-though misspelled in the edition - in the conclusive stanzas of the Abhinavabhäratī, together with Abhinavagupta's father Narasiṃhagupta and his patrilineal ancestor Atrigupta, who moved from Madhyadeśa to Kashmir under King Lalitāditya.

105 I do not know of any comprehensive study on the literary works quoted in the Abhinavabhäratī. Indexes of the authorities and works quoted, with page numbers, can be found at the end of each volume in the Gos edition. A number of quotations from lost works in Prakrit and Apabhramśa are also interspersed in the Dhvanyālokalocana and in the Abhinavabhāratī. On the Prakrit verses quoted in the Locana, see Ingalls et al. 199o. Unfortunately, those from the Abhinavabhäratī have not been listed in the otherwise extremely useful volume by Kulkarni (1988).

106 On the development of the new performance genres, see $\S$ 2.1.

107 To the long commentarial tradition of the Nātyaśāstra in Kashmir prior to Abhinavagupta belong: Bhațta Udbhața (8th c.), Bhaț̣a Lollața (early gth c. CE), Śrī Śankuka (late 9th c.), Bhațța Nāyaka (9th-1oth c.), Kīrtidhara (1oth c.), Bhațta Tauta (1oth c.), and Bhațta Yantra (before the 11th c.). It is not known whether all of them commented on the whole text of the Nātyaśāstra. Bhațta Nāyaka's lost work, the Hṛdayadarpaṇa, or Sahṛdayadarpaṇa, is 
loss is most probably to be found in the great fortune that Abhinavagupta's commentary enjoyed among his contemporaries and successors. Apart from the field of dramatics, in fact, the Nātyaśāstra had become increasingly relevant to the field of poetics (Alaṃkāraśāstra) too, especially in so far as the theory of rasa is concerned. ${ }^{108}$ Long passages from the Abhinavabhäratī on the rasasütra were incorporated almost verbatim into works devoted to poetics, such as Mammata's Kāryaprakāśa. It is possible that the fortune of Abhinavagupta's aesthetic theory in medieval India depended largely on such recastings. ${ }^{109}$

probably an independent work responding to Ānandavardhana's Dhvanyāloka, although he supposedly also wrote a commentary on the Nātyaśāstra (Pollock 2016: 144). For a list of quotations attributed to Bhațta Nāyaka, see Chintamani 1927 and Pollock 2010. Bhațta Tauta might not have written a fully fledged commentary on the Nätyaśāstra or a work on dramatics, although he is certainly the author of the already-mentioned Käryakautuka an independent treatise of poetic content (Pollock 2016: 181). Besides these, other commentaries existed. Abhinavagupta mentions a Bhāssya, a Vārttika, and a Tīkā, as well as other authorities in the fields of music and dance from whom he quotes. It is not known if this earlier tradition was already transmitted with the text of the Nätyaśāstra, or if it developed in Kashmir following the great intellectual and artistic renaissance inaugurated by Jayāpīḍa in the eighth century. In his commentary on the Samgittaratnākara, Kallinātha interestingly identifies Bhațta Nāyaka as the Bhāratīyațīkākāra (Nartanādhyāya, p. 186). If this identification is correct, a closer look at the quotations from the țīkākāra/țīkākrt in the Abhinavabhāratī might broaden our picture of Bhațtanāyaka's work. A certain tradition recorded in later texts on dramatics and in some of the commentaries to the plays wants it that Mātrgupta, allegedly a contemporary of Harșavardhana (7th c.) composed a commentary on the Nätyaśāstra. Following an account in the Rājataraniginīi, Mātrgupta was a poet who later came to rule over Kashmir. Verses of Mātrgupta are quoted by Abhinavagupta, though exclusively in the music chapters. On Mātrgupta, and for a collection of fragments attributed to him, see Chintamani 1928a and Pathak 2009.

108 According to Gnoli, the whole of Indian aesthetics hinged, for generations of rhetors and thinkers, on questions raised and answered while commenting on the rasasūtra ('Out of the union of the determinants, the consequents, and the transitory states, rasa is born', vibhāvānubhāvaryabhicārisamyogād rasanișpattih): 'What is the nature of rasa? What are its relations with the other emotions and states of consciousness? And how are we to understand this word "birth"?' (Gnoli 1968: xv). On Abhinavagupta's rasa theory, see Raghavan 1940; Gnoli 1968; Ingalls et al. 1990; Bansat-Boudon 1992; Gerow 1994; McCrea 2008; Cuneo 2008-2009; and Pollock 2016. On Abhinavagupta's aesthetics, the reader can also refer to Pandey 1950. A number of other works, too numerous to be mentioned, have approached Abhinavagupta's aesthetics from different angles. The relevant bibliography will be referred to as required.

109 The sources incorporating Abhinavagupta's commentary on the rasasūtra are the following: Mammața's Kāryaprakāśa (ca. 1050) and arguably Māṇikyacandra's commentary Sankketa thereon; Hemacandra's Kāryānuśāasana (late 12th c.); Rāmacandra and Guṇacandra's Nätyadarpana (ca. 1200); and the Kalpalatāiviveka, an anonymous subcommentary on Ambāprasāda's lost Kalpalatā (ntth c.?). Viśvanātha's Sāhityadarpaṇa (14th c.), and Jagannātha Paṇịita's Rasagarigādhara (17th c.) also draw on Abhinavagupta's 
It is generally held that a characteristic feature of Abhinavagupta's aesthetics, which he inherited from Bhațta Nāyaka, is its being focused on the experience of the spectator and the epistemology of rasa. ${ }^{110}$ This is doubtless true, insofar as the rasa - the essence and aim of the performance - is analyzed by Abhinavagupta as being located in, and experienced by, the spectator, shifting attention away from a formal analysis of emotions as theatrical objects. However, as argued by Cuneo, the major theoretical novelty characterizing Abhinavagupta's aesthetics and setting him apart from previous thinkers could be recognized in 'the acknowledgement of a clear distinction between aesthetic and common-life (one might also say, pragmatically oriented) emotions, i.e. between emotions aroused by an artwork and emotions aroused by everyday situations. In brief, aesthetic emotions (rasas) are essentially different from ordinary emotions (bhāvas) insofar as the unique ontological status, neither real nor unreal, of the characters and the situations depicted, for example, in a theatrical performance provokes in the spectator a particular type of emotional response, devoid of any form of attachment (räga) or aversion (dveșa) with respect to the emotional stimuli' (Cuneo 2013: 62-63).

Not only is the difference between aesthetic and everyday emotions reformulated ontologically as one of quality and not of quantity (rasa as a distilled and sublimated emotion; cf. Cuneo 2013), but the whole universe of art is reconfigured as essentially non-ordinary or extra-ordinary (alaukika). As I will argue, the ontologically ambiguous status assigned to theatre requires a specific method of performance aimed towards this end: neither a theatre that completely conceals the spectacular machinery, thereby giving the illusion of reality, nor a completely artificial-looking one, given conspicuously to dance, lyricism, and reproducing surreal events. Rather, a theatre moving between these two poles, holding a firm grasp on the spectator's emotional participation in the events depicted, but reminding him from time to time of the fiction through the use of distancing procedures within and beyond the play. ${ }^{111}$ This very idea is implied in Abhinavagupta's complex rethinking of dramatic

aesthetic theory. For details, see Pollock 2016, and for a bibliography on these authors, see Cahill 2004, sub voce.

110 On Abhinavagupta's indebtedness to Bhaț̣a Nāỵaka, see Pollock 2010, 2016: 144-154, 181182, 187-193, and Reich 2018.

111 One of these procedures consists in the purvaranga, where the elements of theatricality are gradually introduced, and the sütradhära - a hybrid form between actor and character, a universalized actor, one may say—makes his first appearance as the celebrant of the complex ritual procedures preceding a play. The sūtradhāra is also the usual protagonist of the prologue (prastāvana $)$, which is already part of the dramatic text and therefore of the fiction. In the prastāvanā, the sütradhāra is already an established role, that of the theatre master in charge of the troupe of actors. In this phase, the planes of reality 
mimesis as divorced from imitation. ${ }^{12}$ In this connection, it is my contention that Abhinavagupta did not create such a concept of theatre ex novo, but rather reinterpreted it on the basis of his own aesthetic assumptions, keeping one eye on the rules of performance as given in the Nätyaśāstra, and the other on the living theatrical traditions existing in his time. Not only did Abhinavagupta have a thorough knowledge of Sanskrit plays as literary texts, but he was also intimately acquainted with theatrical practice, as evidenced even from a superficial perusal of the Abhinavabhäratī.113

By recognizing Abhinavagupta as an authentic sahrdaya, a 'connoisseur' of both dramatic theory and practice, I aim to further an integrated approach to the Abhinavabhāratī, where no substantial rupture is posited between the more evidently spectator-oriented chapters (those on rasa and bhāva), and those that are conspicuously practice-oriented (all the others). The practical perspective is indeed ever present, even in those parts of the commentary specifically devoted to the theory of rasa, and the theory of rasa runs in filigree throughout the treatise as an organizing principle of practice. ${ }^{114}$ Being the only commentary on the totality of the Nātyaśāstra available to us, the Abhinavabhārati is an invaluable source of information on the artistic life of late tenthand early eleventh-century Kashmir. Its exegetical character, however, conceals a double-edged sword: when a particular aspect of practice as described in Bharata's text has become obsolete enough, no longer amenable to verification in the outside world, Abhinavagupta — in this respect a perfect exponent of the doctrine of svātantrya - does not hesitate to take the liberty to twist the meaning of the text of the müla in order to meet his own theoretical requirements. ${ }^{115}$

and fiction gradually blend into one another: it is not uncommon, at the end of the prologue, that the sütradhāra and the națī, the first actress accompanying him, or another assistant, leave the scene as they see the characters of the announced play enter the stage. Other distancing effects are achieved through the device of plays-within-plays or other illusionistic effects, as remarked by Shulman 2012: 38 . As I show in $\S 3.4 .2$, dance and music can also contribute to a distancing effect, emphasizing, through their exuberant character, the extra-ordinary character of theatre.

112 For more on Abhinavagupta's reformulation of dramatic mimesis, see § 3.3.1, § 3.4.2 and $\S 3.5$.

113 As Bansat-Boudon (2005: 161) puts it, 'it would be unrealistic to pretend that Abhinavagupta, the philosopher, is not also an authentic sahrdaya, a passionate lover of drama, which he knows from the inside as an ever-present habitué.

114 An example is the doctrine of the obstacles hindering the proper cognition of theatre, where the various elements of the performance act in different ways to prevent the occurrence of obstructive cognitions invalidating the aesthetic process. A full translation of the passage is available in Gnoli 1968: 62-78, Cuneo 2008-20091: 290-298, and Pollock 2016: 196-201. On the role of dance and acting in this respect, see $\S 3.4$.

115 One such case, with regard to the material in the fourth chapter, is that of the pindība- 
Now, it would be unwarranted to advance the hypothesis that Abhinavagupta's aesthetics originated from the direct observation of existing spectacular practices, since theories can well develop in dialogue with the intellectual speculations preceding them and undergo major changes without necessarily presupposing a corresponding transformation in the objective reality. ${ }^{116}$ But it would not be too far from the truth, I trust, to assume that Abhinavagupta sharpened his theoretical instruments by testing them against the blueprint of the living practices of his time. The arousal of rasa in the spectator is progressively built up, in the Abhinavabhāratī, starting from the composition of the poem, through the right 'emotional configuration', and for the entire duration of the performance, through the different techniques of enactment and beautifying elements such as dance, songs, and music. The different perspectives of the poet, the actor, the spectator, and the performance, one may add, are thus always contemporaneously present, never mutually exclusive. That is why only a close and deep look into the mentioned 'neglected' chapters of this monumental work is liable to eventually disclose new and little-explored perspectives on Abhinavagupta's theory of art.

\subsubsection{The Many Voices Recorded in the Chapter on Dance}

Various thinkers concerned with theoretical development in dramatic theory in the first millennium are known to us through quotations in Abhinavagupta's commentary, especially in the section on the rasasūtra, and in a number of other texts on dramatics and poetics. ${ }^{117}$ Through these sources, we can indirectly recover some of the major developments that the theory of rasa underwent in the lineage of commentaries on the Nātyaśästra inaugurated by Udbhata in the eight century, all composed in Kashmir, and all lost to us.118 Parallel to such theoretical changes, it is quite evident that the multiple artistic disciplines merging in Bharata's work had also undergone significant development in the period separating the root text from its commentary. Even the spectacular object discussed by the treatises had somewhat shifted. Although

ndhas, the study of which has been dealt with in Ganser (forthcoming). The pindîbandhas are mysterious dance movements, usually interpreted as group formations, which in the Abhinavabhäratī become the visual representations of the god's attributes, used to rejoice and propitiate the deities in the preliminaries to the play.

116 See the methodological remarks in the Introduction above. An explicative model that takes changes in the theoretical field as reflections of changes in performance practice was adopted by Gerow (1981: 233) with regard to the rise of a new literary theory by Ānandavardhana, and criticized by McCrea (2008: 1-29).

117 The most complete catalogue of quotations on aesthetics from the early commentators on the Nātyaśāstra is certainly Pollock 2016.

118 On these commentaries, see above, n. 106. 
a new category, grouping together the arts ancillary to theatre (vocal music, instrumental music, and dance) into an independent form of spectacle, the samgìta ('concert'), was to appear only with Saạnngadeva's thirteenth-century Samgitaratnākara, several performative genres containing music and dance in various quantities and permutations had already made their way into the technical texts, as for instance the category of nrtya in Dhanañjaya's tenth-century Daśarüpaka and Dhanika's commentary on it. ${ }^{119}$ A number of different authorities on dance- and music-related topics find their voices through quotation in the Abhinavabhāratī. ${ }^{120}$

Among older authorities recorded in the fourth chapter, we find the names of Kohala ${ }^{121}$, Tumburu, ${ }^{122}$ Rāhula, ${ }^{123}$ Viśākhila, ${ }^{124}$ and an unspecified group

119 See Chapter 2 for a discussion of such new genres and their categories.

120 On authors quoted in the Abhinavabhāratī, see Raghavan 1980: 101-170.

121 On this semi-mythical figure, see Kane 1971: 24-25. Raghavan (1932: 17) noticed that many works are found under the name of Kohala in manuscript libraries, and that at least a work called Samgita Meru, in dialogue style, should be considered as original. Long excerpts from this work are found in the Kalānidhi, Kallinātha's commentary on the Samgìtaratnākara, in particular in the Nartanādhyāya, the seventh chapter, on dance. Fragments attributed to Kohala have been collected by Kane (1933), who situates him after Harșa and before Udbhața, hence roughly between the seventh and eighth centuries CE.

122 In the Mahäbhārata and in the Nātyaśāstra, Tumburu is a Gandharva, a semi-divine being and celestial musician (Goudriaan 1973). In Nś 3.61, he is mentioned, together with Nārada and Viśvāvasu, as a Gandharva presiding on the scene, to be propitiated with mantras. As an author, Tumburu is quoted, to my knowledge, five times in the Abhinavabha $\bar{a}$ rati, although only in the fourth chapter is the reference to his opinion present in all manuscripts, while the other four occurrences are found in vol. 2 of the GOs edition, and they are given in the apparatus without specifying which manuscripts contained those parts. In ABh ad Nś 4.248, vol. 1, p. 161, one verse attributed to Tumburu, on the subject of the recakas, is quoted. On this anuștubh line and a possible correction on the basis of a parallel in the Nrttaratnāvalī, see Raghavan 1980: 187. Tumburu is also mentioned in the Brhaddeśi (ca. 8th c.) as an authority on music.

123 The work of Rāhula is unfortunately lost, except for the sparse quotations in the Abhinavabhäratī and in the Kāryānuśäsana. It is unclear whether he wrote a commentary on Bharata or an independent work. Abhinavagupta mentions Rāhula (also spelled Rāhulaka) five times in different contexts, mostly with regard to acting. In the fourth chapter, two verses of Rāhula are quoted: the first is in the commentary of the karana vaiśäkharecita (ABh ad Nś 1.97cd-98ab, vol. 1, p. 113); the second, about the nātyadharmi ('theatrical convention'), is in the portion edited and translated in this book. His name is mentioned once more with reference to the interpretation of a verse on the connection between abhinaya, dance, and music in the āsāritās (ABh ad Nś 4.299cd-30oab, p. 193). Another two mentions are found in the chapter on the sāmānyābhinaya, where the name Rāhula is preceded by the epithet śäkyācārya, which might suggest his Buddhist affiliation. In a variant given in the apparatus of the Gos edition (vol. 2, p. 208), he is mentioned as one of the 'ancients' (cirantana), although there are no indications of which manuscripts contain this reading. On Rāhula, see Pathak 2009.

124 Viśākhila is the author of a lost work that most probably dealt with the music 
of 'ancients' 125 . Of these authorities, Kohala is a most mysterious figure. Quoted by all later writers on dramatics as a master of theatre and as the inventor or systematizer of new spectacular genres, the uparūpakas, or nrtya types, Kohala makes his appearance already in the Nātyaśāstra, as one of the sons of Bharata and as the author of a 'Second Book'. This has led scholars to suggest that the Nätyaśāstra might have assumed its present form after Kohala's work had been composed, or that he might have even preceded Bharata. According to Abhinavagupta, based on the authority of the followers of Udbhata, the epitome of theatre-formulated in Nś 6.1 as being composed of eleven elements-belongs to Kohala, and he is also quoted with reference to a famous verse on sattva composed by Bharata at the beginning of the chapter on 'harmonious acting' (sāttvikäbhinaya). ${ }^{126}$ In the fourth chapter, Abhinavagupta reports a couple of poetic verses of Kohala on the origin of the practice of enacting songs through dance, and another verse providing a definition of the genre called rāgakārya.

As noticed by Raghavan (1932), in the Abhinavabhäratī, innovations are often presented as Kohala's expansions on the contents of the Nātyaśāstra. The same dynamic seems to be at play in the section of the chapter on dance investigated in the present book. In it, an opponent argues that forms like the Toțaka, the Prakaranikāa, and the Rāsaka are not included in Bharata's definition of the ten dramatic genres, yet they can still be considered theatrical, since 'Kohala mentions them'. In this connection, it might be added that the Abhinavabhärati quotes a group of verses that provide definitions for the new genres and attributes them to some 'ancients' (cirantana), while Hemacandra's Alamkāracūdāmaṇi reproduces the same definitions but attributes them to Kohala. ${ }^{127}$ Although he might have been the author of a treatise on drama including new dramatic genres, the name Kohala appears to me as a sort of stock attribution used to introduce novelty, by the very force of the statement,

chapters of the Nātyaśāstra, of which quotations remain in the Bṛaddeśí, the Dattilam, and the Abhinavabhāratī. Viśākhila is quoted once in the chapter on dance (ABh ad Nś 4.302-303, vol. 1, p. 195) on the topic of lāsya songs (a topic pertaining properly to music), and a number of times in the music chapters as Višākhilācārya, possibly to emphasize his being an authority on the science of music.

125 References to the 'ancients' are made several times in the chapters of the Abhinavabhāratī, but possibly cirantana is a general term referring to different groups of earlier authorities. On the ancients' concept of rasa, see $\S 2.1, n$. 15 .

126 The verse in question is Nś 22.2, which, in an ambiguous passage (ABh ad Nś 4.261cd262ab, vol. 1, p. 169) appears to be attributed to Kohala himself; such at least is the opinion expressed by Kane (1933: 577). For a different interpretation of the passage, and a translation thereof, see Translation 1.6.2, n. 34 .

127 See Translation, 1.6.1, n. 29. 
towards the end of the Nātyaśästra, that 'the rest [of the exposition] will be done by Kohala, by means of a subsequent treatise.'128

At the end of the fourth chapter, various opinions on dance are briefly summarized and connected with a number of authors and authorities: Harșavārttika, Bhațța Yantra, ${ }^{129}$ Bhațta Lollața, ${ }^{130}$ and Kïrtidhara Ācārya. ${ }^{131}$ The first name is, properly speaking, that of a work designated as the 'Gloss of Harșa' (Harșavārttika). Its mention in the chapter on dance is our sole evidence for identifying the author of the Gloss-elsewhere simply mentioned as vārttikakāra, or vārttikakrt -as Harșa. ${ }^{132}$ The opinions of Śrī Harșa are also quoted a few times. All the quotations either of Vārttika or of Śrī Harșa are found in the first six chapters of the Abhinavabhäratī. They are in äryā metre and occasionally in prose. On the three occasions where Abhinavagupta refers to the Varrttika in the fourth chapter, the opinion that dance and theatre are identical since both have an imitative character (tulyānukäratva, ABh ad Nś 4.320, vol. 1,

128 NŚ 37.18ab: śeșam uttaratantrena kohalas tu karisyati |

129 Quoted just once at the end of the fourth chapter of the Abhinavabhäratī.

130 On Bhațta Lollața, one of the commentators on the Nātyaśāstra, famously quoted by Abhinavagupta on the rasasūtra, see Pollock 2016: 74-77.

131 Kīrtidhara or Kīrtidharācārya is mentioned by Śārngadeva as a commentator on Bharata's śāstra. Several quotations are attributed to him in the Abhinavabhāratī. The first appears in the summary of the positions on the nature of dance and theatre at the end of the fourth chapter. In it, Kirtidhara maintains that dance is indeed theatrical in nature, since it contains words to be enacted (abhineyapada) (ABh ad Nś 4.320, vol. 1, p. 204). The opinions of Kïrtidhara on musical items in the pürvaranga are quoted in the geyādhikāra, and one anuștubh is attributed to him in ABh ad Nś 29.95, vol. 4, p. 111. In the same chapter, it is said that the opinions of Kïtidhara regarding the performance of the pürvaranga follow the tradition of Nandikeśvara, to which Abhinavagupta had no direct access, except from quotations in Kīrtidhara's work. Cf. ABh ad Nś 29.111, vol. 4, p. 120: yat kīrtidhareṇa nandikeśvaramatāgamitvena darśitam tad asmābhị̣ sākșān na drșțam. tatpratyayāt tu likhyate saṃkșepatah. Raghavan (1980: 134) maintains that 'though the work on Nandikeśvara was not available to Abhinava, a work called Nandimatam was available to Abhinava', and quotes a verse about the movement called recita, preceded by the indication tathā ca nandimata uktam (ABh ad Nś 4.258bc-259ab, vol. 1, p. 167). In my view, the word nandimata could also be interpreted as the opinion of an author called Nandin or Nandikeśvara: 'The same has been said following the opinion of Nandin', just as expressions such as munimata and bharatamata are often used to refer to Bharata's opinion.

132 Raghavan (1980: 140-147) has collected a number of passages attributed to the author of the Vārttika or Gloss, whom he calls Śrī Harșa. Krishnamachariar (1970: 549) thinks that this Harșa could be the same Śrī Harșadeva, King of Ujjain, who lived in the seventh century CE and composed, among others, the famous play Ratnāvalī. Although the author of the Ratnāvalī, Priyadarśikā, and Nāgānanda displays a thorough knowledge of Bharata's dictates in his plays, there is no evidence that he also wrote a commentary on the Nätyaśästra. Besides, the Abhinavabhäratī is, to the best of my knowledge, the only source to mention it. See Translation, n. 17. 
p. 204) is attributed to it. According to Raghavan (1978: 520), Harșa's Vārtti$k a$ must have dealt with the uparüpakas, based on the identification of the term rāgadarśaniya, appearing in the second quotation from the Vārttika, with rāgakārya, which is the name of one of the uparüpakas in the later tradition. Raghavan's identification is probably correct, however there is no evidence that such a work on the uparūpakas by Harșa ever existed, nor that forms such as the rāgakārya/rāgadarśanīya and others were collectively identified under the label of uparüpaka or something of the sort. Under the name rāgadarśanìya or rägakārya, the author of the Gloss might just have recorded one new spectacular genre among others, without having in mind a single overarching category grouping them all. ${ }^{133}$

Other anonymous commentaries on the Nātyaśāstra appear to have existed, as they are quoted in other chapters of the Abhinavabhäratī. One tīkākāra, for instance, is mentioned several times in the music section, and the various tunes appropriate to the different bhävas and rasas are also indicated as given in this commentary. ${ }^{134}$ Moreover, several opinions by Utpaladeva are reported in the chapters on music, sometimes even as contrary to Abhinavagupta's own position, notwithstanding his status of master in the Pratyabhijñā. This strongly suggests, as argued by Raghavan (1980:121-123) and Rastogi (2017:104-105), that Utpaladeva wrote an independent treatise of musicological content, unfortunately lost and known to us on the sole authority of the Abhinavabhäratí.

A number of quotations in Abhinavagupta's commentary originate from his direct master in dramatics, Bhatta Tauta. These are either attributed to his lost Käryakautuka, or to his direct teachings on the Nätyaśāstra. In the chapter on dance, in particular, Bhatța Tauta/Tota is cited in the context of the entrance of the dancer in the preliminary rite, during the vardhamāna song (ABh ad Nś 4.273, vol. 1, p. 183). He is moreover twice referred to as teacher (upädhyāya): in the commentary on the twenty-first karaña, called vikșiptākșiptakam, he expresses the view that karanas might be used for narrative purposes (ABh ad Nś 4.81cd-82ab, vol. 1, pp. 107-108), ${ }^{135}$ and, at the very end of the chapter, he holds the opinion according to which dance has an invisible result for the dancer, the sponsor of the performance, and the vocalist, and thus differs from theatre (ABh ad Nś 4.320, vol. 1, p. 203). Finally, in connection with the theorization of dance and the new genres, relevant to the present study, Bhatta Tauta is mentioned with regard to the Ḍombikā called Cüḍamaṇi (ABh ad Nś 31.331,

\footnotetext{
133 See Translation 2.4.1, n. 65 .

134 On the possible identification of the țīkākāra with Bhațta Nāyaka, see n. 106 above.

135 On the use of karanas for abhinaya as a major novelty of the Abhinavabhäratī, but possibly an innovation already voiced by Bhatța Tauta, see $\S 2.2$, and n. 61 .
} 
vol. 4, p. 271), a form of performance treated at length in the passage edited in this book, particularly interesting for the new conceptualization of narrative dance. ${ }^{136}$

From this polyphonic mosaic of opinions and vivid descriptions of dance practices and genres, it emerges that the commentator's discourse on the nature and purpose of dance did not develop in a theoretical and artistic void; on the contrary, a number of sources and authorities on music and dance existed and were known to Abhinavagupta. The fourth chapter of the Abhinavabhāratī is therefore a crucial source for studying the practice and aesthetic of Indian dance in the first millennium.

${ }_{13} 6$ On the Dombikā as a model for narrative dance, see $\S 3.5$. On this passage, attributed to the Käryakautuka, and its parallels in the section translated here, see Translation, n. 39. 